\title{
Starting from a Blank Page? Semantic Similarity in Central Bank Communication and Market Volatility
}

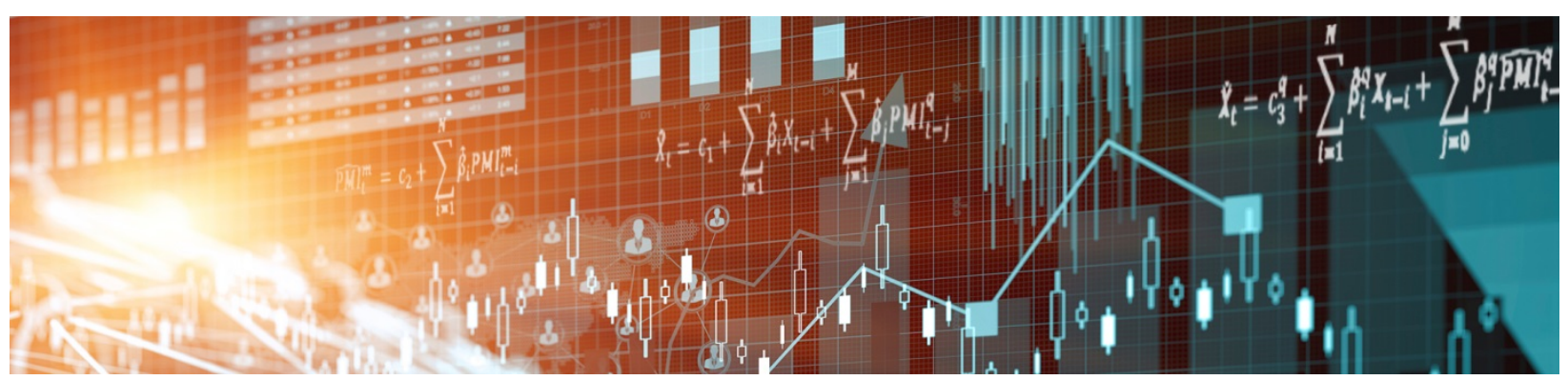

by Michael Ehrmann and Jonathan Talmi 
Bank of Canada Staff Working Paper 2016-37

July 2016

\title{
Starting from a Blank Page? Semantic Similarity in Central Bank Communication and Market Volatility
}

\author{
by \\ Michael Ehrmann and Jonathan Talmi \\ Economic and Financial Research \\ Bank of Canada \\ Ottawa, Ontario, Canada K1A OG9 \\ mehrmann@bankofcanada.ca \\ jtalmi@bankofcanada.ca
}




\section{Acknowledgements}

We would like to thank Chris Hau for help with the data, and Oleksiy Kryvtsov, Yuko Imura and seminar participants at the Bank of Canada for helpful comments. 


\begin{abstract}
Press releases announcing and explaining monetary policy decisions play a critical role in the communication strategy of central banks. Because of their market-moving potential, it is particularly important how they are drafted. Often, central banks start from the previous statement and update the earlier text with only small changes. This way, it is straightforward to compare statements and see how the central bank's thinking has evolved. This paper studies to what extent such similarity in central bank statements matters for the reception of their content in financial markets. Using the case of the Bank of Canada (the G7 central bank that had to rely the least on unconventional monetary policy following the global financial crisis and has therefore broadly continued standard monetary policy communications), the paper shows that press releases with larger differences in wording lead to higher volatility in financial markets, suggesting that their content is more difficult to absorb. At the same time, while press releases that are similar to the previous one generate less market volatility, once their wording is updated, volatility increases substantially.

JEL classification: E43, E52, E58

Bank classification: Central bank research; Financial markets; Interest rates
\end{abstract}

\title{
Résumé
}

Les communiqués de presse annonçant et expliquant les décisions en matière de politique monétaire jouent un rôle essentiel dans la stratégie de communication des banques centrales. Étant donné l'influence que ces communiqués peuvent avoir sur les marchés, la façon dont ils sont rédigés revêt une importance particulière. Souvent, les banques centrales se basent sur la déclaration précédente, qu'elles mettent à jour en n'apportant que de petits changements. Il est alors facile de comparer les déclarations et de faire le point sur l'évolution des réflexions des banques centrales. Cette étude analyse la mesure dans laquelle une telle similarité des déclarations des banques centrales influe sur la réception de leur contenu dans les marchés financiers. Les auteurs, qui prennent pour exemple la Banque du Canada (la banque centrale d'un pays du G7 qui a dû le moins compter sur des mesures de politique monétaire non traditionnelles après la crise financière mondiale et qui a par conséquent, d'une manière générale, maintenu sa stratégie de communication au sujet de la politique monétaire), montrent que les communiqués présentant des différences de formulation plus importantes entraînent une accentuation de la volatilité des marchés financiers, ce qui laisse entendre que leur contenu est plus difficile à assimiler. Parallèlement, les communiqués qui se ressemblent d'une publication à l'autre génèrent une volatilité moindre des marchés, mais cette 
dernière s'intensifie considérablement à partir du moment où la formulation est actualisée.

Classification JEL : E43, E52, E58

Classification de la Banque : Recherches menées par les banques centrales; Marchés financiers; Taux d'intérêt 


\section{Non-technical summary}

Central bank statements that announce and explain monetary policy decisions are closely watched by financial market participants and have been shown to be important market movers. In the light of this, central banks put a lot of effort into the drafting of these statements. Often, central banks use the previous statement as their starting point and modify the text wherever needed. While the obvious advantage of such an approach is that new information is easy to grasp, there might also be downsides. As the economy evolves, the central bank might be faced with a choice to either keep a similar wording (which might constrain what and how the central bank can communicate) or update the wording more fundamentally (at which point the new content might be harder to assess for central bank watchers who are expecting only marginal changes). Not surprisingly, therefore, different approaches have been followed not only by different central banks but also over time.

This paper studies to what extent the similarity of central bank statements matters for their reception in financial markets. If, indeed, the information content of similar statements is easier to grasp, there should be less disagreement among central bank watchers about their interpretation and market prices should adjust quickly to their new fundamental value. In contrast, if statements are harder to interpret, prices should take longer to adjust. In the context of our analysis, this translates into testing whether the similarity of press releases affects volatility in financial markets, once we have controlled for the content of the communication, the surprise component contained in the monetary policy decision and the degree of uncertainty in financial markets.

We focus on the responsiveness of 1-year government bond yields to 110 Bank of Canada press releases from 2001 to 2015 but show that our results hold across a large number of financial markets, covering short- to long-term interest rates, exchange rates and stock markets. The key findings are as follows: First, in line with the existing literature, we show that the forward-looking part of communications in particular matters for financial markets. Second, in terms of content, statements about the domestic economy appear to be the most relevant. Third, similarity matters for the reception of the central bank's communication in financial markets. Controlling inter alia for the content of communications, we find that less similar press releases are associated with larger volatility, suggesting that market participants find it more difficult to assess their content. This seems to favour a communication approach in which central banks start from the previous press release rather than from a blank page. However, we also provide evidence that the reaction of market volatility to press releases depends on the content of the previous press releases-volatility increases substantially more if dissimilar press releases follow a sequence of very similar press releases. Our interpretation of this result is that, while similar press releases are easier to digest, this comes at a cost when at some point the wording is adjusted more fundamentally. At that point in time, markets might find it harder to interpret the new wording, having become accustomed to marginal updates of earlier press releases and presumably expecting another similar press release.

We therefore conclude that both starting from the previous press releases and starting from a blank page are viable communication strategies. While similar press releases appear to be easier to interpret in the short run, this is not necessarily the case over a longer horizon. It is important to stress that other factors need to be considered when choosing a communication strategy. For instance, central banks need to take into account whether similar press releases impose a constraint on what the central bank can communicate. We leave this issue for future research. 


\section{Introduction}

Central bank statements that announce and explain monetary policy decisions are closely watched by financial market participants and have been shown to be important market movers (for an overview of the relevant literature, see Blinder et al. 2008). In the light of this, central banks put a lot of effort into the drafting of these statements. Often, central banks use the previous statement as their starting point and modify the text wherever needed. This practice has shaped the way financial newswire services report about central bank statements: Prior to the release, they often re-report the key sentences of the previous statement, reminding market participants of the starting point of the text that is expected to be in the upcoming release. Immediately after the statement is released, services like Bloomberg publish side-by-side comparisons with the previous one: any changes are highlighted in both Bank of Canada and FOMC statements. Bloomberg also publishes a version of the FOMC statement with additions from the previous statement underlined and deletions shown with strikeout. Bloomberg's side-by-side comparisons are published roughly a minute and half after the press release.

While using the previous statement as a starting point has the obvious advantage of making it easy for market participants to identify new information, there may also be downsides to this approach. As the economy evolves, the central bank might be faced with a choice to either keep a similar wording (which might constrain what and how the central bank can communicate) or update the wording more fundamentally (at which point the new content might be even harder to assess for central bank watchers who are expecting only marginal changes). Not surprisingly, therefore, different approaches have been followed not only by different central banks but also over time. Bank of Canada Governor Stephen S. Poloz, for instance, has announced that he prefers to start writing each press release with a blank page. ${ }^{1}$

This paper studies to what extent the similarity of central bank statements matters for their reception in financial markets. If, indeed, the information content of similar statements is easier to grasp, there should be less disagreement among central bank watchers about their interpretation and market prices should adjust quickly to their new fundamental value. In contrast, if statements are harder to interpret, prices should take longer to adjust. In the context of our analysis, this translates into testing whether the similarity of press releases affects volatility in financial markets, once we have controlled for the content of the communication, the surprise component contained in the monetary policy decision and the degree of uncertainty in financial markets.

The paper uses the Bank of Canada as its testing case, for two reasons. First, unlike most other advanced-economy central banks, the Bank of Canada has barely resorted to using unconventional monetary policy tools in the aftermath of the global financial crisis. Accordingly, the content of its monetary policy communications has been relatively stable, allowing for a meaningful analysis over a much longer time period than would be feasible for most other central banks. Our sample covers 110 press releases from 2001 to 2015, all appearing at regular intervals. Second, the way these press releases have been drafted has undergone substantial changes. For some time, portions of the press releases were virtually identical or changed only marginally. More recently, the press releases have become less similar, reflecting the current governor's preference for starting from a blank page. Accordingly, the Bank of Canada offers an interesting case with a sufficient amount of variation that allows for a meaningful comparison over time.

\footnotetext{
${ }^{1}$ Comment made during the press conference on 17 July 2013; see also http://blogs.wsj.com/canadarealtime/2014/03/05/poloz-brings-change-to-the-bank-and-its-statements/.
} 
We focus on the responsiveness of 1-year government bond yields to the Bank of Canada press releases that announce its monetary policy decisions but show that our results hold across a large number of financial markets, covering short- to long-term interest rates, exchange rates and stock markets. The key findings are as follows: First, in line with the existing literature, we show that the forward-looking part of communications in particular matters for financial markets. Second, in terms of content, statements about the domestic economy appear to be the most relevant. Third, similarity matters for the reception of the central bank's communication in financial markets. Controlling inter alia for the content of communications, we find that less similar press releases are associated with larger volatility, suggesting that market participants find it more difficult to assess their content. This seems to favour a communication approach in which central banks start from the previous press release rather than from a blank page. However, we also provide evidence that the reaction of market volatility to press releases depends on the content of the previous press releases-volatility increases substantially more if dissimilar press releases follow a sequence of very similar press releases. Our interpretation of this result is that, while similar press releases are easier to digest, this comes at a cost of larger volatility when at some point the wording is adjusted more fundamentally. At that point in time, markets might find it harder to interpret the new wording, having become accustomed to marginal updates of earlier press releases and presumably expecting another similar press release.

We therefore conclude that both starting from the previous press releases and starting from a blank page are viable communication strategies. While similar press releases appear to be easier to interpret in the short run, this is not necessarily the case over a longer horizon. When choosing a communication strategy, central banks need to take other considerations into account, such as whether similar press releases impose a constraint on what the central bank can communicate, an issue that is beyond the scope of this paper.

The remainder of this paper is organized as follows. A review of the most relevant related literature is provided in section 2. The third section discusses the data and methodology used in the analysis. Section 4 provides some insights into the content of the Bank of Canada press releases and its evolution over time, and section 5 presents the empirical findings and reports the results of robustness tests. A discussion of the conclusions and implications follows in section 6.

\section{Related Literature}

This paper relates to the extensive literature on the effect of macroeconomic announcements on asset prices. Early contributions have studied the release of macroeconomic data and have documented the responsiveness of stock prices (McQueen and Roley 1993), money and bond markets (Fleming and Remolona 1999; Thornton 1998), and exchange rates (Andersen et al. 2003; Faust et al. 2007). This early evidence has been refined in subsequent work in various ways, in particular with regard to identifying which data releases are most important and why (see, e.g., Gilbert et al. 2016).

A related literature (surveyed in Blinder et al. 2008) has focused on news released by central banks and how it is received in financial markets. Central bank communications have been found to be among the most important market movers, not only for interest rates (Guthrie and Wright 2000; Kohn and Sack 2004; Andersson et al. 2006; Ehrmann and Fratzscher 2007a) but also for exchange rates via regular monetary policy 
communications (Sager and Taylor 2004; Melvin et al. 2009; Conrad and Lamla 2010) as well as through communications about the exchange rate, i.e., via "oral exchange rate interventions” (Jansen and de Haan 2005; Fratzscher 2006; Dewachter et al. 2014).

Among the many types of communications by central banks, those on behalf of the entire policy-making committee are particularly strong market movers (Reinhart and Sack 2006; Reeves and Sawicki 2007). The most important component of central bank communication on behalf of the entire committee is clearly the announcement of policy decisions and the surrounding communication. Gürkaynak et al. (2005) show that both monetary policy actions and statements by the Federal Reserve have important but differing effects on asset prices, with statements having a much greater impact on longerterm Treasury yields, a finding that is confirmed by Brand et al. (2010) for the European Central Bank (ECB).

A few papers have studied Bank of Canada communications in particular. Macklem (2005) provides an overview of how the Bank of Canada has become more transparent over time, in line with the overall trend among central banks. Hendry (2012) shows how the Bank of Canada's press releases on its fixed announcement dates (i.e., when it announces its monetary policy decisions) affect volatility in short-term interest rates. Hayo and Neuenkirch (2012a) use a GARCH model—as we do here-to study the effects of central bank communication and macroeconomic news on Canadian bond, stock and foreign exchange market returns and their volatility. They show that communication by the Bank of Canada is more relevant than communication by the U.S. Federal Reserve, whereas U.S. macro news exerts larger effects than Canadian news-findings that are in line with the earlier results reported in Gravelle and Moessner (2002). Hayo and Neuenkirch (2012b) differentiate between the original communication by the Bank of Canada and newswire reports, showing that bond markets react more to the original communication, while newswire reports are more relevant for the stock market. Finally, Fay and Gravelle (2010) show that, with the inclusion of forward-looking statements in the Bank's press releases, markets focus less on the discussion of the economic outlook and therefore respond less than before to new macroeconomic data releases.

The focus of this paper is the similarity of central bank statements, an area covered by very few earlier papers. Jansen and de Haan (2010) test the extent to which ECB communication has used consistent language over time and find consistency overall, even though the ECB's communication has been flexible enough to adapt to changing circumstances. Acosta and Meade (2015) study the similarity of subsequent FOMC postmeeting statements and demonstrate that these have become substantially more similar over time and especially so since the global financial crisis. However, they also show that it is important to measure the semantic content of the statements appropriately, since their semantic content is less similar and more variable than what a comparison of the raw language would suggest. Interestingly, while FOMC statements have become more similar since the crisis, they have also become more complex, as shown by HernándezMurillo and Shell (2014). This is important because more complex statements are associated with higher volatility in financial markets, a point that is demonstrated by Jansen (2011) for the Humphrey-Hawkins testimonies by the Chairperson of the FOMC. ${ }^{2}$ A closely related paper is Amaya and Filbien (2015), which looks at the case of the ECB and finds that similarity has been increasing over time, helping stock markets digest the information more easily.

\footnotetext{
${ }^{2}$ For international comparisons of the complexity of central bank communication and their determinants, see Bulíŕ et al. (2013a) and Bulíŕ et al. (2013b).
} 
A common theme across all papers in the central bank communication literature is the preparation of the raw text for econometric analysis. In the current paper, we need to explore this in two ways. First, we measure the content and the tone of the communication, since these will be important control variables; second, we measure the similarity of two subsequent press releases. With regard to the first dimension-the measurement of the tone and the content of central bank communications-there are mainly two different approaches in the previous literature. On the one hand, several studies have used human coding, arguing that automated language processing is not suitable to pick up subtle nuances in language-especially given the complex language often used by central banks (Ehrmann and Fratzscher 2007a; Conrad and Lamla 2010; Neuenkirch 2013). On the other hand, a number of recent papers have used automated procedures, highlighting in particular that this approach guarantees consistency and replicability of results, as well as less subjectivity (Lucca and Trebbi 2009; Hansen and McMahon 2015; Schmeling and Wagner 2016). In this paper, we position ourselves in the middle of this debate. We use human coding to measure the tone and content of communication and also because we are interested in differentiating forward-looking from backward-looking statements, which, to our knowledge, has not yet been done in an automated fashion. At the same time, we will use an automated approach to measure the semantic similarities of consecutive statements. We will apply this method to whole statements as well as their (human-coded) subcategories. . In doing so, we follow the approach of Acosta and Meade (2015), which lends itself naturally to automation.

\section{Data and Empirical Methodology}

In this section, we outline our estimation methodology and the data we use for our empirical analysis.

\subsection{Data}

\section{Measuring the tone of the press releases}

With regard to the Bank of Canada's communications, we focus on the press releases that accompany the announcement of interest rate decisions. As discussed previously, these arguably constitute the most important piece of monetary policy communication on behalf of the entire policy-making committee. There are eight such releases each year. Currently, for four of them, the Bank of Canada simultaneously releases its Monetary Policy Report (MPR), and the Governor and Senior Deputy Governor subsequently hold a press conference. It is important to note, however, that until the end of 2012 (i.e., for the majority of our sample period), the MPR was released on a different date than the press release. For simplicity, we will therefore abstract from the content of the MPR and accompanying press conference in our analysis and focus exclusively on the press release. We will, however, test to what extent the release of the MPR influences the effect of press releases. We also abstract from other Bank of Canada communications, such as speeches, since these do not occur on the same day or even in the week before the press release, given that the Bank adheres to a blackout period. ${ }^{3}$

As mentioned above, we rely on human coding to measure the tone of the press releases. In a nutshell, we break a press release into blocks of words, code the tone of these and

\footnotetext{
${ }^{3}$ See http://www.bankofcanada.ca/core-functions/monetary-policy/key-interest-rate/blackout-guidelines/.
} 
then aggregate the blocks of words into an overall indicator. ${ }^{4}$ This procedure involves four steps.

In step 1, we categorize blocks of words in each press release into one of the following four topics, which were included in the press releases in a relatively consistent manner throughout the sample period: domestic economy, the global economy, inflation and foreign exchange. If required, we split sentences into different parts to reflect that these belong to a different category. Following are a few examples (for a full list, please refer to Table A1 in the appendix): A statement about the domestic economy would be "The Canadian economy continued to expand in the first quarter of 2003, reflecting firmness in domestic demand." A statement about the global economy is "Strong growth in the United States is expected to resume in the second quarter of 2015." One on inflation is "Canadian consumer price data for January show core inflation at 1.8 per cent and total CPI inflation at 1.3 per cent." And a statement related to the exchange rate is "The Canadian dollar has traded in a higher range against the U.S. dollar and other major currencies.”

In step 2, we differentiate the blocks of words into statements that talk about the past, i.e., provide a backward-looking assessment of the state of the economy or of monetary policy, and statements that talk about the future, i.e., provide a forward-looking assessment. The global economy statement above is an example for a forward-looking statement ("is expected to resume"); the domestic economy statement is a backwardlooking statement ("continued to expand”).

In step 3, we further differentiate the blocks of words according to tone, differentiating positive, neutral and negative statements. We code indications that economic growthboth domestically and globally - is picking up (slowing down) and that inflation edges higher (lower) as positive (negative) to indicate that such developments would imply higher (lower) interest rates going forward. For example, the statement "Inflation has risen by more than expected" is coded as positive; "The Canadian economy has been growing broadly in line with the Bank's expectations" as neutral; and "Although temporary supply chain disruptions are expected to restrain growth sharply in the current quarter...” as negative.

With regard to the exchange rate, we code a currency appreciation (depreciation) as positive (negative), with the underlying idea that an appreciating Canadian dollar is a reflection of a stronger economy. This is in line with the high correlation of the Canadian dollar with commodity prices and the fact that Canada is a large commodity exporter. This coding might be controversial, since an appreciating currency would tend to lower exports, implying decreasing import prices (and thus it could imply a negative outlook for interest rates). We have tested for the robustness of our results to the coding of exchange rate statements in two ways: by reversing the coding and by excluding the exchange rate statements entirely (when we study the effect of statements about other topics in isolation). We find our results to be robust.

Following these 3 steps, we now have word blocks that are differentiated according to topic, tense and tone-with 4 topics, 2 tenses and 3 tones, there are 24 different categories.

In step 4, we count the number of words in each category and aggregate them to our variable of interest, the balance of words for each press release. This is defined as

\footnotetext{
${ }^{4}$ We look at the entire press release, but exclude common "operational” phrases such as the introductory paragraph, which announces the interest rate decision itself, or an often-used final paragraph, which underscores the Bank’s mandate to keep inflation close to its target.
} 


$$
\text { balance }_{i, \tau}=\frac{w c_{i, p o s i t i v e, \tau}-w c_{i, n e g a t i v e, \tau}}{w c_{i, p o s i t i v e, \tau}+w c_{i, n e u t r a l, \tau}+w c_{i, n e g a t i v e, \tau}}
$$

where $w c$ denotes the word counts, $i$ is the category and $\tau$ is the press release. Note that we scale these balances by the total number of words in the category to allow for different length in press releases over time. We construct such balance variables for the entire press release (where we aggregate over all topics and both tenses), for the forwardlooking part and for the backward-looking part (where we aggregate over all topics, but separately for each tense) and for each topic (where we aggregate over both tenses for each topic). These variables give an indication of the tone of a given press release with respect to the specific topic or tense, or overall.

\section{Measuring the similarity across different press releases}

Our second measure of the content of press releases relates to the similarity of subsequent press releases, following the approach proposed by Acosta and Meade (2015). This approach involves calculating the cosine similarity (distance) between two fixed-length vector representations of pairs of press releases. First, we subject the raw text to several preprocessing steps: (i) We remove the introductory paragraph announcing the interest rate decision because it is contained in every press release using virtually the same language, which would bias the similarity measure upward. (ii) We convert the text into lowercase and remove punctuation, dates, numbers and stop words (common words with no meaningful interpretation such as articles and pronouns). ${ }^{5}$ (iii) We concatenate a few words that have special meaning when appearing together (such as "bank of canada" to "bankofcanada") because leaving them separated might bias the similarity measure upward. ${ }^{6}$ (iv) We split the remaining text into individual words through a process called "tokenization," and "stem" each word down to its root. ${ }^{7}$ (v) We tabulate the list of unique words used in the body of the press releases and record how often each word appears in each press release. (vi) We multiply each unique word by a scaling factor $\ln \left(n / n_{w}\right)$, where $n$ is the total number of press releases and $n_{i}$ is the number of press releases where word $w$ appears. ${ }^{8}$ This assigns higher weights to words that appear rarely and lower weights to words that appear frequently in the corpus, thus allowing us to emphasize subtle differences in language.

Following these steps, we calculate the cosine similarity for each consecutive pair of press releases. The cosine similarity between any two press releases $\tau$ and $\tau^{*}$ is

$$
S_{\tau, \tau^{*}}=\frac{\sum_{w=1}^{W} f r_{w, \tau} f r_{w, \tau^{*}}}{\left(\sqrt{\sum_{w=1}^{W} f r_{w, \tau}^{2}}\right)\left(\sqrt{\sum_{w=1}^{W} f r_{w, \tau^{*}}^{2}}\right)},
$$

where $W$ is the total number of unique words that ever appeared in one of the press releases (i.e., the entire corpus of text), and $f r_{w, \tau}$ and $f r_{w, \tau *}$ are the frequencies of word $w$ in press releases $\tau$ and $\tau^{*}$. Two press releases with the exact same set of words and frequencies have $s_{\tau, \tau^{*}}=1$ and are perfectly similar; two press releases that use none of

\footnotetext{
${ }^{5}$ We use the publicly available list of English stop words in the Natural Language Toolkit for Python 2.7.

${ }^{6}$ We concatenate or abbreviate the following eight phrases: "monetary policy report update” to "mpru,"

"monetary policy report” to”mpr," "bank of canada” to "bankofcanada," "federal reserve” to

"federalreserve," "federal funds rate” to "fedfundsrate," “united states” to "unitedstates," “ u.s.” to

"unitedstates," and "per cent” to "percent."

${ }^{7}$ Stemming involves removing suffixes and inflections from the end of words so that all the derivatives of a word stem have the same form, e.g., "increase," "increases," "increasing," and "increasingly" are all stemmed down to "increas."

${ }^{8}$ This is often referred to as a TF-IDF (term frequency-inverse document frequency) weighting scheme.
} 
the same words are orthogonal—or perfectly dissimilar-with $s_{\tau, \tau^{*}}=0$. Importantly, this measure does not depend on the order of the words in the text.

As we did for the balance measures, we calculate semantic similarities for the press releases in their entirety, as well as separately for the forward-looking and the backwardlooking parts and for each topic. In addition, we calculate the semantic similarity for the last paragraph of each press release only, given that the last paragraph is particularly important in communicating the Bank’s outlook for monetary policy. ${ }^{9}$

\section{Financial market data}

Regarding the dependent variable, we focus our analysis on the 1-year government bond yields, sourced from Bloomberg, since this is the maturity that has been shown to be most affected by announcement effects (Fleming and Remolona 1999) and is among the most liquid. We collect the data at the daily frequency and use the first differences as our dependent variable. We consider a daily frequency to be an appropriate frequency for our type of analysis. As is common in the announcement literature, our identification assumption is that the central bank news (i.e., the monetary policy decision and the surrounding communication) dominates all other news during the time window that we analyze, i.e., that any change in market prices occurs as a reaction to this news. The higher the frequency, the more plausible this assumption. However, whereas intra-day data would allow a more precise measurement of the announcement effects (since fewer other events and news may introduce noise into the analysis), daily data allow us to account for potential overshooting effects in the very short run.

For testing the effect on other maturities and other markets, we also collected data from Bloomberg, namely for government bond yields at the 3-month, 6-month, 2-year, 5-year, 10-year and 30-year maturity; money market rates at the 3-month, 6-month and 1-year maturity; the MSCI stock index for Canada and the USD-CAD exchange rate. We also include a measure of the Canadian effective exchange rate provided by the Bank of Canada. ${ }^{10}$ We use first differences for the interest rates and daily growth rates for stock indices and exchange rates as our dependent variables. Table A2 in the appendix provides summary statistics for the various financial market variables.

To estimate the effect of the Bank of Canada's communication on financial markets, it is crucial to control for the surprise component contained in the announced monetary policy decision. For that purpose, we follow the vast announcement literature (e.g., Ehrmann and Fratzscher 2007b) and construct the surprise component as the difference between the announced decision and market expectations, where the latter are measured by the mean expectation recorded in a Bloomberg survey.

\section{Sample period}

Our sample starts on 1 November 2001 and ends on 16 July 2015, comprising a total of 110 press releases and 3,431 trading days. The starting date of the sample is determined by the availability of a measure of the surprise component contained in monetary policy

\footnotetext{
${ }^{9}$ If a subcategory appears in a press release but does not appear in the subsequent press release, the similarity is equal to 0 (since the current press release is perfectly dissimilar to the preceding one). Press releases that follow this release that have no content from the subcategory have similarities of 1 (since they are perfectly similar to the preceding one). When the subcategory reappears, the current press release's similarity is equal to 0 (since it is perfectly dissimilar to the preceding press release).

${ }^{10}$ See http://www.bankofcanada.ca/rates/exchange/ceri/.
} 
decisions. The Bank of Canada moved to a system of eight pre-announced policy decision dates in 2000. Subsequently, Bloomberg implemented in the autumn of 2001 its survey about the upcoming Bank of Canada monetary policy decisions. We begin the sample in November 2001, using the October 2001 press release as a starting point for constructing the similarity index in order to exclude the extraordinary press release following the terrorist attacks of 11 September 2001.

\subsection{Estimation methodology}

As mentioned above, we are interested in the response of 1-year government bond yields to the Bank of Canada's press releases. A natural econometric framework for this purpose is to use an ARCH-type model, which enables us to measure simultaneously the effects for the conditional means and the conditional variances. We estimate a GARCH model, following Bollerslev (1986) and Engle (2001). A GARCH $(1,1)$ model is sufficient to address the non-normality of the data, in particular the serial correlation and heteroscedasticity of the daily returns.

The conditional mean equation is formulated as

$$
r_{t}=\alpha_{0}+\alpha_{1} r_{t-1}+\beta_{s} s_{t}+\beta_{\text {bal }} \text { balance }_{t}+\mu_{t} .
$$

In line with much of the related literature, we estimate the model over all business days in the sample, i.e., including days when the Bank of Canada does not announce its interest rate decisions. Accordingly, $t$ denotes trading days. $r_{t}$ is the change in 1-year government bond yields, and $r_{t-1}$ their lagged values. ${ }^{11}$ The variable $s_{t}$ denotes the surprise component contained in the announced interest rate decision, which we enter in order to separate the effect of the interest rate decision from the effect of the surrounding communication. The main variable of interest is the variable balance $e_{t}$, which contains the tone of the press release (entered in different variants, as explained above). The variables $s_{t}$ and balance $_{t}$ are equal to zero on days when the Bank of Canada does not announce its interest rate decisions, given that there is no news. Our hypotheses are that a positive surprise component contained in the announced interest rate decision as well as a relatively more positive press release will raise interest rates, i.e., that $\beta_{s}>0$ and $\beta_{b a l}>0$.

The specification of the mean equation is interesting in itself, but it is also important to ensure that we identify the coefficients in the variance equation appropriately. A failure to control for all relevant factors in the mean equation will lead to larger residuals, which in turn raise conditional variance $h_{t}$. Our assumption is that the distribution of the disturbance is $\mu_{t} \sim\left(0, h_{t}\right)$. We express the conditional variance as

$$
h_{t}=\gamma_{0}+\gamma_{1} \mu_{t-1}^{2}+\gamma_{2} h_{t-1}+\delta_{s}\left|s_{t}\right|+\delta_{\text {sim }} \text { similarity }_{t} .
$$

Here, the surprise component contained in the announced interest rate decision has an absolute value and enters the equation to separate the effect of the interest rate decision from the effect of the surrounding communication. similarity $y_{t}$ denotes the semantic similarity. We set similarity ${ }_{t}$ to 1 on days without press releases-since there is no news on such days, the content of the earlier press release is still "in place," implying perfect similarity. Our hypotheses are that larger absolute surprises and more similar press releases lower volatility, i.e., $\delta_{s}>0$ and $\delta_{s i m}<0$. The latter hypothesis is based on the idea

\footnotetext{
${ }^{11}$ We include a second lag if the second lag turns out to be statistically significant. Adding further controls, such as day of the week effects, does not affect our results.
} 
that relatively similar statements make it easy to grasp their content. If that is the case, there should be less disagreement among central bank watchers about their interpretation and market prices should adjust quickly to their new fundamental value. In contrast, if statements are harder to interpret, prices should take longer to adjust. In line with this reasoning, we would expect to see that more-similar press releases lower volatility.

The model is estimated via maximum likelihood, using the BHHH and BFGS algorithms.

Beyond the 1-year government bond yields, we also test the effect on interest rates of different maturities, the exchange rate return or the stock market return. We include additional control variables $x_{k, t}$ for exchange rate returns, namely the contemporaneous rate of growth in energy commodity prices, the contemporaneous rate of growth in nonenergy commodity prices and the change in the interest rate differential relative to the United States, as measured by 3-month rates and for stock returns (the contemporaneous return on the U.S. S\&P500). ${ }^{12}$

\section{The Content of the Bank of Canada Press Releases and its Evolution over Time}

Quantifying the Bank of Canada's communications allows us to better understand its content and how this has evolved over time.

Figures 1 and 2 here

Figure 1 plots the number of words in each press release, along with a moving average that facilitates the visualization of medium-term trends. Overall, press releases have become considerably longer-doubling from around 200 words at the beginning of our sample to around 400 words at the end of the sample, with a peak of around 600 words in 2011 (i.e., when the Bank of Canada provided additional guidance to market participants to correct their views about the pace of future tightening, see Carney 2012). The increased forward-looking nature of the Bank of Canada's communications during the sample is also mirrored in the upper part of Figure 2, which plots the share of forwardand backward-looking text in the press releases.

The lower part of Figure 2 breaks the content into different topics and highlights that, by far, the largest share of words deals with the domestic economy, with inflation coming second. Discussions of the global economy gained more prominence after the financial crisis, becoming the second most important category for some time, but falling back to third position more recently. Finally, the exchange rate constitutes a relatively small share throughout the entire sample period.

Tables 1 and 2 here

Table 1 provides summary statistics for the variables that measure the tone and semantic similarity of the press releases. Looking first at the tone of the press releases (Panel B), we find that, because of the long sample period under study, the tone of the press releases is close to zero on average. This is certainly the case not only when looking at the press releases in their entirety but also for most subcategories. Interestingly, there is a wide variation over time, with the tone ranging from -0.91 (very negative) to +0.95 (very positive) over all the press releases and spanning the entire possible range from -1 to +1 for the various subcategories that we identify.

\footnotetext{
${ }^{12}$ The energy and non-energy commodity indices are from the Bank of Canada; all other series are from Bloomberg (Amano and van Norden 1998; Issa, Lafrance and Murray 2008).
} 
Looking at the correlation over time in Panel A of Table 2, it is apparent that the overall tone is reflected both in the backward- and the forward-looking parts of the press releases and in the discussion of domestic economic developments (all of which have a correlation coefficient of around 0.8 with the tone in the entire press release). The correlation is smallest for the discussion of foreign exchange developments. Interestingly, while there is a similar correlation between the entire press release and both the backward- and forward-looking components, the correlation between the backward- and forward-looking components themselves is much smaller, at 0.33, suggesting that these two dimensions are clearly separate.

\section{Table 3 here}

To gauge whether our measure of tone captures the content of the Bank of Canada press releases in a meaningful way, we ran a few simple tests along the lines suggested by Sturm and de Haan (2011), Hayo and Neuenkirch (2011), and Rosa (2009), who all studied whether the tone of central bank communications can help predict future policy rate changes. This is done using ordered probit models to account for the fact that policy rates are typically changed in multiples of 25 basis points (which is also the case in our sample). We calculate robust standard errors. Table 3 reports the results, for the entire press release and for the backward- and forward-looking components. For each of these, we test whether the tone of a given press release explains policy rate changes at the next meeting, two meetings out or three meetings out.

We find that the tone has explanatory power for decisions not only at the subsequent meeting but also two meetings ahead. Despite the simplicity of our models, we explain a non-trivial amount of the variation in the data with a pseudo R2 of up to 0.12 . Somewhat surprisingly, however, the tone of forward-looking statements is less relevant than the tone of backward-looking statements. Overall, however, these results indicate that our measure of tone is a meaningful proxy for the content of the press releases.

Figure 3 here

Turning to the semantic similarity, the press releases in their entirety show an average similarity of 0.27 (see Panel C of Table 1), much lower than the corresponding estimate of 0.65 obtained for the United States in Acosta and Meade (2015). There is considerable variation over time, with the index ranging from 0.07 to 0.64 . Looking at the time trend depicted in Figure 3, similarity had been trending up over the period from 2007 to 2013 and declined substantially afterward. Similar time trends are observed for the last paragraph (even though the changes in magnitude are much larger than those of the similarity of the entire press releases), the parts dealing with the domestic economy, and backward- and forward-looking statements, although the variations are more pronounced in the forward-looking parts. As was the case for the tone of the press release, we find that the various components are generally highly correlated in terms of similarity (Panel B of Table 2).

\section{Semantic Similarity and Market Volatility}

\subsection{Effects on 1-year government bond yields}

We next report the empirical results. Our first model contains the variables that have been traditionally part of the announcement effect literature-the surprise component contained in the monetary policy decision in the mean equation and its absolute value in the variance equation. As expected, we find that this matters (see the first column in 
Table 4). A surprise tightening tends to raise interest rates nearly one to one, and larger absolute surprises tend to raise volatility in interest rates.

\section{Table 4 here}

In the next step, we expand our model to include the tone variable in the mean equation and the semantic similarity in the variance equation. Results are reported in column 2 of Table 4. The first noticeable result is that by controlling for the tone of the press release, the estimated coefficients for the surprise component contained in the monetary policy decision remain statistically significant, but become smaller-somewhat for the surprise in the mean equation and markedly so for the absolute surprise in the variance equation. This suggests that the traditional models, which do not control for the content of the accompanying communication, overstate markedly the effect of the surprise component in a given decision.

Financial markets are responsive to the tone of the press releases. Press releases that are, on balance, optimistic (pessimistic), i.e., have a positive (negative) value for the balance variable tend to raise (lower) bond yields. A one-standard-deviation change in this variable changes bond yields by around one basis point. While statistically significant, the effect is economically small. Also the semantic similarity matters in the expected direction: relatively more-similar press releases are associated with lower market volatility, suggesting that they are more straightforward to interpret. In terms of economic magnitude, a one-standard-deviation change in semantic similarity would lead to a onebasis-point larger residual, a change along the interdecile range to a residual that is larger by two basis points. While this sounds relatively small, it is important to keep in mind that the average absolute residual on press release dates amounts to four basis points, suggesting that differences in semantic similarity can explain a relatively large amount of the residual variation in government bond yields.

Columns 3 to 8 of Table 4 report results when we control for different components of the entire press release. As mentioned above, we run separate regressions for each component because the various parts are highly correlated. When differentiating between backward- and forward-looking statements, it is apparent that the tone of both matters for interest rates. Forward-looking statements have a larger coefficient, but the difference is small. In contrast, the tense matters when it comes to similarity. For backward-looking statements, we find no statistically significant effect in the variance equation, whereas the coefficient for forward-looking statements is large in magnitude and highly statistically significant. This is in line with Conrad and Lamla (2010) and Hansen and McMahon (2016), who show that markets react more to the forward-looking component of the ECB's and the Federal Reserve's communications than to the backward-looking component.

Regarding the different types of content, statements about the domestic economy appear to be the most important part of the press releases, as shown by both a large coefficient of the tone in the mean equation and a large effect of similarity in the variance equation. This is not surprising, given that they constitute the largest share of the content of the press releases. Statements about the global economy and inflation affect interest rates via their tone, but their similarity is not important in explaining market volatility.

\subsection{Effects on other financial markets}

The focus of our analysis so far has been on 1-year government bond yields. Table 5 shows results for our benchmark specification (which captures the effects of the press 
releases in their entirety) across different maturities and for money markets, exchange rates and the stock market. Tightening surprises in monetary policy decisions raise bond yields along most of the maturity spectrum (and easing surprises lower them). We reproduce the well-known hump-shaped pattern that had been identified for the United States by Fleming and Remolona (1999), whereby the effect increases with longer maturities and subsequently decreases, to finally fade out at the 30-year maturity. Tightening surprises also appreciate the exchange rate, whereas we (surprisingly) cannot identify an effect on stock market returns. Looking at the variance equation, we find that larger absolute surprises tend to raise volatility in interest rates, whereas-perhaps somewhat surprisingly-there is no discernible effect on exchange rates and stock markets.

\section{Table 5 here}

Turning to the tone of the press release, our findings for 1-year yields are confirmed-a positive tone raises interest rates, once more with a hump-shaped pattern. Interestingly, the peak is reached at the 2-year maturity, i.e., at a longer maturity than the maximum effect of the surprise component in the monetary policy decision. This is consistent with the notion that press releases contain forward-looking information and therefore affect yields further out in the maturity spectrum (Gürkaynak et al. 2005; Brand et al. 2010).

Similarity, in contrast, is relevant until the 1-year maturity. It also has the expected effect on exchange rates but does not appear to be significant for stock returns. Based on these results, Canadian stock markets are generally not responsive to Bank of Canada actions and communications. While this is surprising, similar findings have been reported in the earlier literature (Hayo and Neuenkirch 2012b).

\subsection{Interaction effects}

To summarize the findings discussed so far, it seems that more-similar statements are beneficial in the sense that they lead to less market volatility, presumably because they make it simpler for markets to understand how the Bank's view evolves. But is this a general finding that is true under all circumstances?

To look into this question, we focus on the last paragraph of the press releases. For some time, these have been used as key paragraphs to provide an outlook for the monetary policy stance, with very similar language. ${ }^{13}$ This is immediately apparent in the relevant plot in Figure 3, which reveals that there have been several instances where the wording in the last paragraph was identical to its predecessor (i.e., our semantic similarity measure is 1). Interestingly, when such identical paragraphs were eventually changed (which could happen after one or repeated occurrences), the update tended to be quite substantial, leading to a rather low semantic similarity. Accordingly, this measure shows rather large swings. To see whether our earlier findings also apply to the last paragraph, we report results for our benchmark specification in the first column of Table 6. Results are robust; we even get a slightly larger log likelihood than we do for the benchmark model.

\section{Table 6 here}

The large swings in this variable raise the question of whether volatility is low when statements are extremely similar and increases relatively more once such statements get updated. We test this hypothesis in the following manner. First, we construct a dummy

\footnotetext{
${ }^{13}$ http://blogs.wsj.com/canadarealtime/2014/03/05/poloz-brings-change-to-the-bank-and-its-statements/
} 
variable for the 33\% most-similar last paragraphs in our sample. Any last paragraph with a semantic similarity above 0.49 falls into this category. Second, we run regressions using a slightly altered variant of the conditional variance equation as follows:

$$
h_{t}=\gamma_{0}+\gamma_{1} \mu_{t-1}^{2}+\gamma_{2} h_{t-1}+\delta_{s}\left|s_{t}\right|+\delta_{\text {sim }} \text { similarity }_{t}+\delta_{D} D_{t_{-1}}+\delta_{\text {interact }} \text { similarity }_{t} D_{t_{-1}} \text {, }
$$

where $D_{t_{-1}}$ denotes the newly created dummy variable lagged by one press release (meaning that it is equal to one when the previous last paragraph was extremely similar to the one before). Our hypothesis is that the market is more sensitive to similarity if the previous statements were extremely similar, because it is apparent that the central bank has updated its assessment in a more substantive manner, but it is relatively more difficult to identify and interpret the parts of the text that are relevant. Accordingly, we would expect $\delta_{\text {interact }}<0$.

Column 2 of Table 6 reports the corresponding results. We do indeed find $\delta_{\text {interact }}<0$ and, in addition, that $\delta_{D}>0$. To illustrate what this implies, let us look at the following table, which reports the estimated parameter values under different cases - on the one hand, when the previous last paragraphs had been extremely similar or not; on the other hand, for different values of the semantic similarity, namely minimum, mean and maximum (see also Table 1):

\begin{tabular}{|c|c|c|c|}
\hline & similarity $_{t}=0$ & similarity $_{t}=0.382$ & similarity $_{t}=1$ \\
\hline$D_{t_{-1}}=0$ & 0.000 & -1.573 & -4.119 \\
\hline$D_{t_{-1}}=1$ & 3.614 & -0.285 & -6.592 \\
\hline
\end{tabular}

There are several things to note in the table above. First, the benchmark case is the one where $D_{t_{-1}}=0$ and similarity ${ }_{t}=0$. For that constellation, the overall effect on volatility is zero. Second, moving to the right in the table shows that with increasing similarity, volatility decreases, regardless of the content of the previous statements (i.e., in both rows of the table). This simply repeats the earlier findings. Third, if we take the extreme case where a highly similar statement is followed by an entirely orthogonal statement (which is represented by the lower left entry in the table), volatility increases substantially. In contrast, repeating the same text for the third time or more often (the case of the lower right entry in the table when $D_{t_{-1}}=1$ and similarity ${ }_{t}=1$ ), volatility decreases by even more than when the statement is repeated for the first time.

What these findings suggest is that markets find it increasingly easier to interpret statements if they keep getting repeated. In contrast, when statements are eventually updated, market volatility is relatively larger.

Columns (3) and (4) of Table 6 report results for another extension of the regression. We added the change in the length of the press releases (as measured by the change in the overall word count) and find that increases in length lower volatility (column (3)). In addition, there is an interesting interaction term when we estimate

$$
h_{t}=\gamma_{0}+\gamma_{1} \mu_{t-1}^{2}+\gamma_{2} h_{t-1}+\delta_{s}\left|s_{t}\right|+\delta_{\text {sim }} \text { similarity }_{t}+\delta_{\Delta w c} \Delta w C_{t}+\delta_{\text {interact }} \text { similarity }{ }_{t} \Delta w c_{t} .
$$

To facilitate the interpretation of these results, let us tabulate the coefficients for different scenarios: 


\begin{tabular}{|c|c|c|c|}
\hline & similarity $_{t}=0$ & similarity $_{t}=0.382$ & similarity $_{t}=1$ \\
\hline$\Delta w c_{t}=-150$ & -0.150 & -0.732 & -1.674 \\
\hline$\Delta w c_{t}=0$ & 0.000 & -2.244 & -5.874 \\
\hline$\Delta w c_{t}=+150$ & 0.150 & -3.756 & -10.074 \\
\hline
\end{tabular}

For high levels of similarity, lengthening the press release lowers volatility, in line with additional clarity being provided by the additional content. Analogously, shortening the press release while maintaining a high level of similarity leads to higher volatility, suggesting that the shorter statement provides less clarity. This relationship holds for the mean and maximum levels of similarity (as shown by the coefficients in the last two rows of the table above). Interestingly, however, the relationship reverses at low levels of similarity. To take the extreme case of similarity ${ }_{t}=0$, i.e., two orthogonal press releases, we find that lengthening the press releases raises volatility, whereas shortening them lowers volatility. While the effect is quantitatively small, it suggests that a completely different statement is easier to understand if it is short than if it is long.

\subsection{Robustness tests}

We conduct a large number of robustness tests of our benchmark estimation, the effect of similarity in the entire press release on 1-year government bond yields. Column 1 in Table 7 repeats that benchmark for easier comparison with the various robustness results. As mentioned earlier, the way we code the tone of statements related to foreign exchange might be controversial. Given the small share of these statements in the press releases, we would not expect this to matter and indeed find that the overall results are robust when we reverse the coding (see column 2). In a second robustness test, we added a measure of uncertainty about the economy and monetary policy, namely the interquartile range across forecasters of the three-month interest rates three months out in Consensus Economics (following Dovern et al. 2012). This variable in itself is positively related to conditional volatility, but its addition does not alter our results qualitatively.

\section{Table 7 here}

For parsimony of our econometric models and to facilitate convergence of our estimators, we abstracted from macroeconomic news, despite the fact that there is a large literature that documents their relevance for financial markets. Fortunately, since no indicators are systematically released on the same days as the Bank of Canada press releases, we do not expect our results to change materially when adding macroeconomic news. This is indeed the case, as seen in column 4. We added several Canadian and U.S. releases, following the earlier announcement literature for Canada (Gravelle and Moessner 2002). The variables account for the surprise component in the releases by subtracting the median expectation among forecasters in the corresponding Bloomberg survey from the actual announcement, normalized by the standard deviation of the surprise. The amount of macro news does indeed affect yields - higher than expected Canadian employment, U.S. non-farm payrolls and U.S. retail sales increase government bond yields, and large absolute surprises in Canadian producer prices, U.S. non-farm payrolls, U.S. industrial production and U.S. retail sales increase volatility. The sign of these coefficient estimates are all in line with theory. The only exception is a surprising negative effect of the 
absolute surprises in Canadian employment. Most importantly for our purposes, all results regarding the communication variables are robust.

The next test looks into the way we enter the tone of the press release. As mentioned earlier, we were somewhat surprised by the relatively small effect of tone on yield changes. An alternative specification is to explain yield changes by the changes in the balance variable between consecutive statements, rather than by the balance variable itself. Such a test is reported in column 5. It shows that both specifications are viable. The coefficients are broadly unchanged, and the log likelihood is very close, with our original specification performing a little bit better.

Our subsequent test controls for another aspect of the Bank of Canada communications in the conditional variance equation, namely a dummy variable for press releases that coincide with the release of the Bank's Monetary Policy Report (MPR). The MPR contains the Bank's projections and a narrative around the Bank's assessment of the economic situation and the stance of monetary policy. It can therefore provide additional information to markets; press releases on MPR dates are actually around 100 words longer, on average (even though similarity is not statistically significantly lower). Market volatility is slightly lower in MPR months (with the estimated coefficient significant at the $10 \%$ level), and the effect of semantic similarity remains significant. ${ }^{14}$

The last column of Table 7 checks for the sensitivity of our results to the estimation methodology. When estimating an EGARCH model, our results hold. This is important since the GARCH model assumes that both positive and negative news have a symmetric effect on volatility. It has often been argued that this assumption is violated, because bad news might lead to higher volatility than good news would. Even though this point has typically been made for stock returns, we want to allow for this possibility in our context as well. However, it does not appear to be a relevant concern in our case.

Additional tests that, for brevity, we do not report show that lags of the absolute surprise variable and of the semantic similarity to the conditional variance equation are insignificant.

\section{Conclusions}

Over the past few years, several central banks have released press statements that show an increasing semantic similarity. Often, the previous release is used as a starting point for drafting the subsequent version. An advantage to this practice is it is easy to identify where the central bank has updated the text. According to our results, another advantage is that the evolution of the central bank's views is more easily understood-relatively similar statements are absorbed by financial markets with lower volatility. Importantly, this effect is identified after controlling for the content of the press release.

However, at some point, any statement must be updated more materially, and we find that, in these instances, market volatility increases. We therefore conclude that both starting from the previous press releases and starting from a blank page are viable communication strategies. While similar press releases appear to be easier to interpret in the short run, this is not necessarily the case over a longer horizon.

It is important to stress that other factors need to be considered when choosing a communication strategy. For instance, central banks need to take into account whether

\footnotetext{
${ }^{14}$ The effect of similarity in MPR months is not different from its effect in other months, as shown by an insignificant interaction term (not shown for brevity).
} 
similar press releases impose a constraint on what the central bank can communicate. We leave this issue for future research. 


\section{References}

Acosta, M. and E. Meade (2015). Hanging on every word: Semantic analysis of the FOMC's postmeeting statement. FEDS Notes, 30 September 2015, available at https://www.federalreserve.gov/econresdata/notes/feds-notes/2015/semantic-analysis-of-theFOMCs-postmeeting-statement-20150930.html.

Amano, R. and S. van Norden (1998). Exchange Rates and Oil Prices. Review of International Economics 6, 683-694.

Amaya. D. and J.-Y. Filbien (2015). The similarity of ECB's communication. Finance Research Letters 13, 234-242.

Andersen, T. G., T. Bollerslev, F. X. Diebold and C. Vega (2003). Micro Effects of Macro Announcements: Real-Time Price Discovery in Foreign Exchange. American Economic Review 93, 38-62.

Andersson, M., H. Dillen and P. Sellin (2006). Monetary Policy Signaling and Movements in the Term Structure of Interest Rates. Journal of Monetary Economics 53, 1815-1855.

Blinder, A., M. Ehrmann, M. Fratzscher, J. de Haan and D.-J. Jansen (2008). Central bank communication and monetary policy: a survey of theory and evidence. Journal of Economic Literature 46, 910-945.

Bollerslev, T. (1986). Generalized Autoregressive Conditional Heteroskedasticity. Journal of Econometrics 31, 307-327.

Brand, C., D. Buncic and J. Turunen (2010). The Impact of ECB Monetary Policy Decisions and Communication on the Yield Curve. Journal of the European Economic Association 8, 12661298.

Bulír, A., M. Čihák and D.-J. Jansen (2013a). What Drives Clarity of Central Bank Communication About Inflation? Open Economies Review 24, 125-145

Buliřr, A., M. Čihák and K. Šmídková (2013b). Writing Clearly: The ECB’s Monetary Policy Communication. German Economic Review 14, 50-72.

Carney, M. (2012). Guidance, speech at CFA Society Toronto, available at http://www.bankofcanada.ca/2012/12/guidance/.

Conrad, C. and M. Lamla (2010). The high-frequency response of the EUR-USD exchange rate to ECB communication. Journal of Money, Credit and Banking 42, 1391-1417.

Dewachter, H., D. Erdemlioglu, J.-Y. Gnabo and C. Lecourt (2014). The intra-day impact of communication on euro-dollar volatility and jumps. Journal of International Money and Finance 43, 131-154.

Dovern, J., U. Fritsche and J. Slacalek (2012). Disagreement among Forecasters in G7 Countries. Review of Economics and Statistics 94, 1081-1096.

Ehrmann, M. and M. Fratzscher (2007a). Communication by Central Bank Committees: Different Strategies, Same Effectiveness? Journal of Money, Credit and Banking 39, 509-41. 
Ehrmann, M. and M. Fratzscher (2007b). Transparency, Disclosure, and the Federal Reserve. International Journal of Central Banking 3, 179-225.

Engle, R. (2001). GARCH 101: The Use of ARCH/GARCH Models in Applied Econometrics. Journal of Economic Perspectives 15, 157-168.

Faust, J., J. Rogers, S. Wang, and J. Wright (2007). The High-Frequency Response of Exchange Rates and Interest Rates to Macroeconomic Announcements. Journal of Monetary Economics 54, 1051-68.

Fay, C. and T. Gravelle (2010). Has the Inclusion of Forward-Looking Statements in Monetary Policy Communications Made the Bank of Canada More Transparent? Bank of Canada Staff Discussion Paper 2010-15.

Fleming, M. J. and E. M. Remolona (1999). The Term Structure of Announcement Effects. Federal Reserve Bank of New York Staff Report No. 76.

Fratzscher, M. (2006). On the long-term effectiveness of exchange rate communication and interventions. Journal of International Money and Finance 25, 146-167.

Gilbert, T., C. Scotti, G. Strasser and C. Vega (2016). Is the Intrinsic Value of Macroeconomic News Announcements Related to their Asset Price Impact? ECB Working Paper No. 1882.

Gravelle, T. and R. Moessner (2002). Reactions of Canadian Interest Rates to Macroeconomic Announcements: Implications for Monetary Policy Transparency. Journal of Bond Trading and Management 1, 27-43.

Gürkaynak, R., B. Sack and E. Swanson (2005). Do Actions Speak Louder Than Words? The Response of Asset Prices to Monetary Policy Actions and Statements. International Journal of Central Banking 1, 55-93.

Guthrie, G. and J. Wright (2000). Open Mouth Operations. Journal of Monetary Economics 46, 489-516.

Hansen, S. and M. McMahon (2015). Shocking Language: Understanding the macroeconomic effects of central bank communication. Centre for Macroeconomics Discussion Paper No. 1537.

Hayo, B. and M. Neuenkirch (2011). Canadian Interest Rate Setting: The Information Content of Canadian and U.S. Central Bank Communication. Southern Economic Journal 78, 131-148.

Hayo, B. and M. Neuenkirch (2012a). Domestic or US news: What drives Canadian financial markets? Economic Inquiry 50, 690-706.

Hayo, B. and M. Neuenkirch (2012b). Bank of Canada communication, media coverage, and financial market reactions. Economics Letters 115, 369-372.

Hendry, S. (2012). Central Bank Communication or the Media's Interpretation: What Moves Markets? Bank of Canada Working Paper No. 2012-9. 
Hernández-Murillo, R. and H. Shell (2014). Rising Complexity of the FOMC Statement. Economic Synopses 23, available at https://research.stlouisfed.org/publications/economicsynopses/2014/11/05/the-rising-complexity-of-the-fomc-statement/.

Hubert, P. (2016). Disentangling Qualitative and Quantitative Central Bank Influence, available at http://hubertpaul.free.fr/Disentangling_Qual_Quant_CB_Inf.pdf.

Issa, R., R, Lafrance and J. Murray (2008). The Turning Black Tide: Energy Prices and the Canadian Dollar. Canadian Journal of Economics 41, 737-59.

Jansen, D.-J. (2011). Does the Clarity of Central Bank Communication Affect Volatility in Financial Markets? Evidence from Humphrey-Hawkins Testimonies. Contemporary Economic Policy 29, 494-509.

Jansen, D.-J. and J. de Haan (2005). Talking heads: the effects of ECB statements on the eurodollar exchange rate. Journal of International Money and Finance 24, 343-361.

Jansen, D.-J. and J. de Haan (2010). An Assessment of the Consistency of ECB Communication using Wordscores, DNB Working Paper No. 259.

Kohn, D. L., and B. P. Sack (2004). Central Bank Talk: Does It Matter and Why? In Macroeconomics, Monetary Policy, and Financial Stability, 175-206. Ottawa: Bank of Canada.

Lucca, D. O. and Francesco Trebbi (2009). Measuring Central Bank Communication: An Automated Approach with Application to FOMC Statements, available at http://www.nber.org/papers/w15367.

Macklem, T. (2005). Commentary: Central Bank Communication and Policy Effectiveness. Federal Reserve Bank of Kansas City Proceedings - Economic Policy Symposium - Jackson Hole, 475-494.

McQueen, G. and V. Roley (1993). Stock Prices, News, and Business Conditions. Review of Financial Studies 6, 683-707.

Melvin, M., C. Saborowski, M. Sager and M. P. Taylor (2009). Bank of England interest rate announcements and the foreign exchange market. International Journal of Central Banking 6 , 211-247.

Neuenkirch, M. (2013). Monetary policy transmission in vector autoregressions: A new approach using central bank communication. Journal of Banking and Finance 37, 4278-4285.

Reeves, R. and M. Sawicki (2007). Do Financial Markets React to Bank of England Communication? European Journal of Political Economy 23, 207-227.

Reinhart, V. and B. Sack (2006). Grading the Federal Open Market Committee's Communications. Mimeo, Board of Governors of the Federal Reserve System (January).

Rosa, C. (2009). Forecasting the Direction of Policy Rate Changes: The Importance of ECB Words. Economic Notes 38, 39-66. 
Sager, M. J. and M. P. Taylor (2004). The impact of ECB Governing Council announcements on the foreign exchange market: a microstructural analysis. Journal of International Money and Finance 23, 1043-1051.

Schmeling, M. and C. Wagner (2016). Does Central Bank Tone Move Asset Prices?, available at http://papers.ssrn.com/sol3/papers.cfm?abstract_id=2629978.

Sturm, J.-E. and J. de Haan (2011). Does central bank communication really lead to better forecasts of policy decisions? New evidence based on a Taylor rule model for the ECB. Review of World Economics 147, 41-58.

Thornton, D. L. (1998). Tests of the Market’s Reaction to Federal Funds Rate Target Changes. Review (Federal Reserve Bank of St. Louis) 80, 25-36. 
Figure 1: Length of Bank of Canada press releases

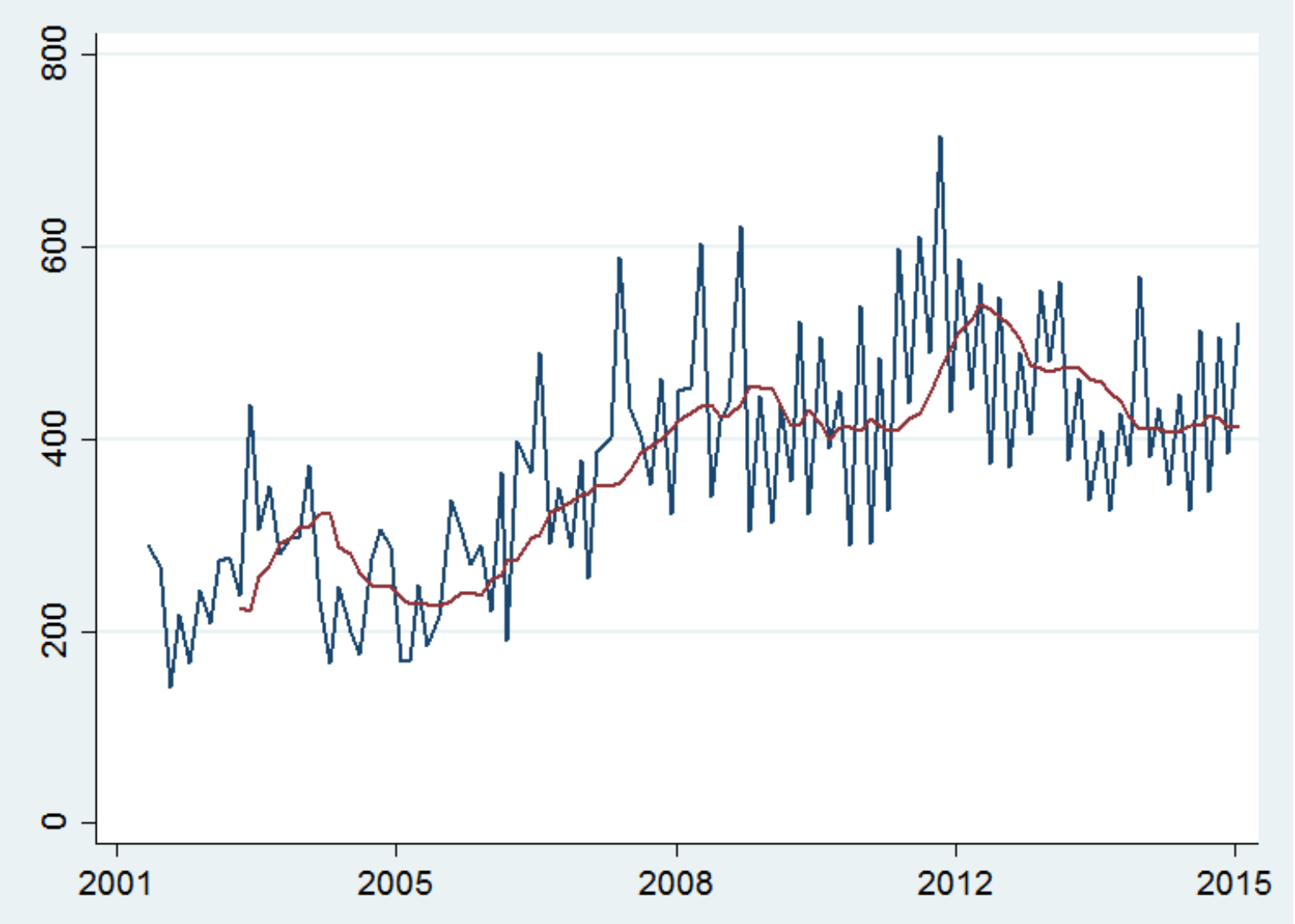

Notes: The figure shows the number of words of the Bank of Canada press releases (blue line) and a moving average covering the previous eight press releases (red line). 
Figure 2: Content of Bank of Canada press releases
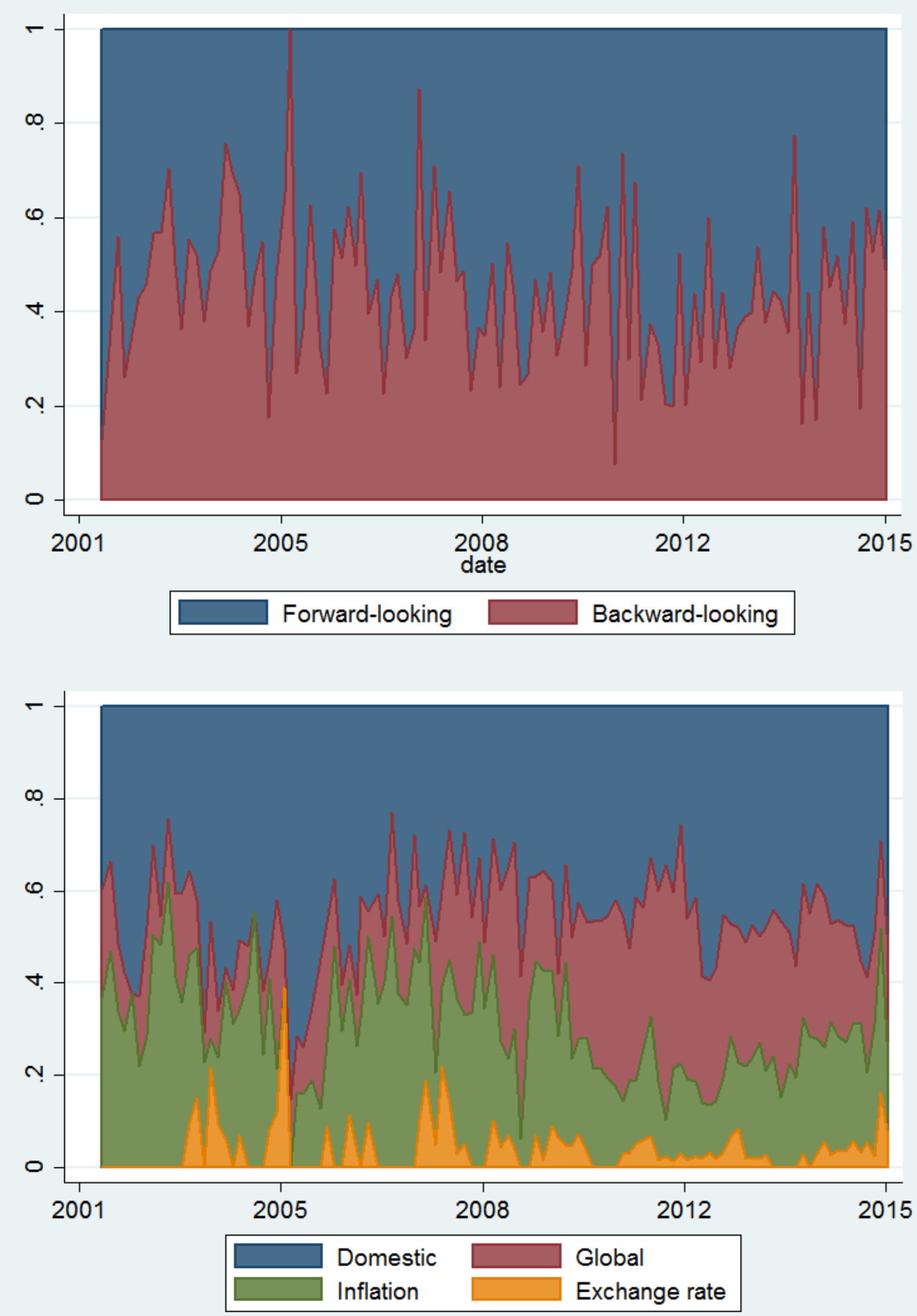

Notes: The figure shows the share of words that are allocated to backward- and forward-looking statements (Panel A) and to each topic (Panel B) in the Bank of Canada press releases. 
Figure 3: Semantic similarity of Bank of Canada press releases
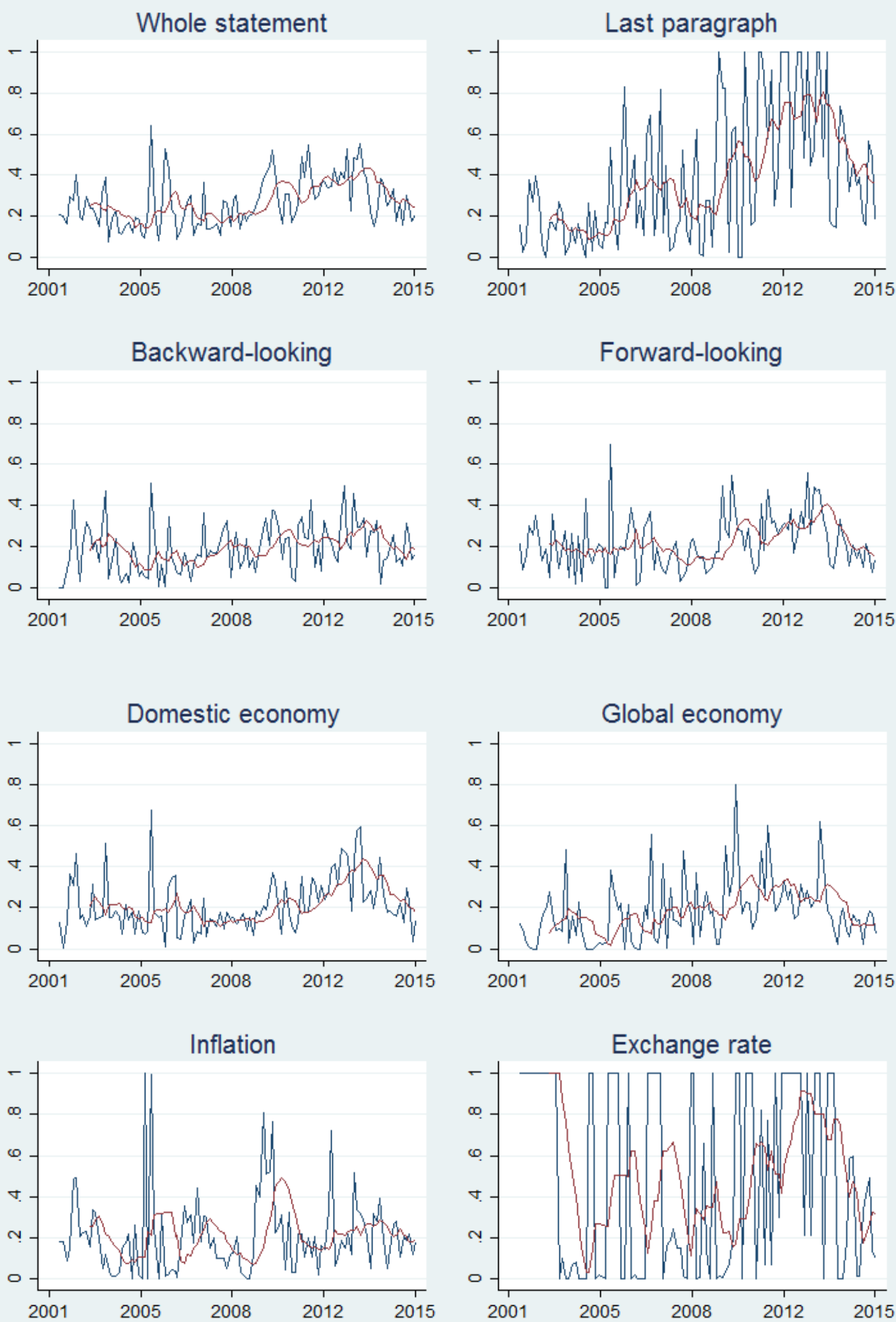

Notes: The figure shows the semantic similarity of the Bank of Canada press releases (blue line), measured as described in equation (2) and an eight-press-release moving average (red line). 
Table 1: Summary statistics for central bank communications variables

\begin{tabular}{c|ccccc}
\hline \hline Variable & Obs & Mean & Std. Dev. & Min & Max \\
\hline A: Surprises & & & & & \\
Mean & 110 & -0.008 & 0.066 & -0.250 & 0.258 \\
Absolute mean & 110 & 0.030 & 0.059 & 0.000 & 0.258 \\
\hline B: Tone & & & & & \\
Total & 110 & 0.023 & 0.345 & -0.905 & 0.951 \\
Backward-looking & 110 & 0.046 & 0.503 & -1.000 & 1.000 \\
Forward-looking & 110 & -0.014 & 0.385 & -1.000 & 1.000 \\
Domestic & 110 & 0.103 & 0.448 & -1.000 & 1.000 \\
Global & 110 & -0.122 & 0.546 & -1.000 & 1.000 \\
Inflation & 110 & -0.096 & 0.510 & -1.000 & 1.000 \\
Exchange rate & 110 & 0.290 & 0.691 & -1.000 & 1.000 \\
\hline C: Similarity & & & & & \\
Total & 110 & 0.270 & 0.122 & 0.073 & 0.640 \\
Last paragraph & 110 & 0.382 & 0.321 & 0.000 & 1.000 \\
Backward-looking & 110 & 0.192 & 0.118 & 0.000 & 0.510 \\
Forward-looking & 110 & 0.219 & 0.133 & 0.000 & 0.696 \\
Domestic & 110 & 0.213 & 0.131 & 0.006 & 0.674 \\
Global & 110 & 0.182 & 0.153 & 0.000 & 0.800 \\
Inflation & 110 & 0.214 & 0.194 & 0.000 & 1.000 \\
Exchange rate & 110 & 0.500 & 0.460 & 0.000 & 1.000 \\
\hline \hline
\end{tabular}

Notes: The table shows summary statistics for the surprise component contained in monetary policy decisions in Panel A, the tone of the Bank of Canada press releases in Panel B and the semantic similarity of the Bank of Canada press releases in Panel C. 
Table 2: Correlation of central bank communications variables

\begin{tabular}{l|lllllll}
\hline \hline A: Tone & Entire & Backward & Forward & Domestic & Global & Inflation & Exchange rate \\
\hline Entire release & 1.0000 & & & & & & \\
Backward-looking & 0.7992 & 1.0000 & & & & & \\
Forward-looking & 0.7902 & 0.3328 & 1.0000 & & & & \\
Domestic & 0.8413 & 0.6553 & 0.7002 & 1.0000 & & & \\
Global & 0.3876 & 0.1670 & 0.4207 & 0.2285 & 1.0000 & & \\
Inflation & 0.6611 & 0.6267 & 0.4429 & 0.3836 & -0.0411 & 1.0000 & \\
Exchange rate & 0.0399 & 0.1687 & -0.1290 & -0.0227 & -0.0615 & -0.0563 & 1.0000 \\
\hline \hline
\end{tabular}

\begin{tabular}{l|cccccccc}
\hline \hline B: Similarity & Entire & Last para. & Backward & Forward & Domestic & Global & Inflation & Exchange rate \\
\hline Entire release & 1.0000 & & & & & & & \\
Last paragraph & 0.6439 & 1.0000 & & & & & & \\
Backward-looking & 0.5822 & 0.2597 & 1.0000 & & & & & \\
Forward-looking & 0.7141 & 0.4433 & 0.3904 & 1.0000 & & & & \\
Domestic & 0.7039 & 0.4253 & 0.5481 & 0.7179 & 1.0000 & & & \\
Global & 0.5883 & 0.3802 & 0.5219 & 0.4350 & 0.3930 & 1.0000 & & \\
Inflation & 0.3535 & 0.1792 & 0.3043 & 0.4469 & 0.3138 & 0.1651 & 1.0000 & 1.0000 \\
Exchange rate & 0.2144 & 0.1420 & 0.0953 & 0.2407 & 0.2572 & 0.1277 & 0.0774 & \\
\hline \hline
\end{tabular}

Notes: The table shows correlation coefficients of the variables measuring the tone of the Bank of Canada press releases in Panel A and the variables measuring the semantic similarity of the Bank of Canada press releases in Panel B. 
Table 3: The predictive power of the tone of Bank of Canada press releases

\begin{tabular}{l|ccc|ccc|ccc}
\hline \hline & \multicolumn{3}{|c|}{ Entire press release } & \multicolumn{3}{c|}{ Backward-looking } & \multicolumn{3}{c}{ Forward-looking } \\
& $1^{\text {st }} l a g$ & $2^{\text {nd }} l a g$ & $3^{\text {rd }} l a g$ & $1^{\text {st }} l a g$ & $2^{\text {nd }} l a g$ & $3^{\text {rd }} l a g$ & $1^{\text {st }} l \operatorname{lag}$ & $2^{\text {nd }} l a g$ & $3^{\text {rd }} l a g$ \\
\hline Balance variable & $1.613^{* * *}$ & $0.773^{* * *}$ & 0.163 & $1.251^{* * *}$ & $0.653^{* * *}$ & 0.229 & $0.675^{* *}$ & 0.310 & -0.015 \\
& $(0.367)$ & $(0.289)$ & $(0.274)$ & $(0.229)$ & $(0.193)$ & $(0.201)$ & $(0.274)$ & $(0.267)$ & $(0.258)$ \\
\hline Observations & 110 & 110 & 110 & 110 & 110 & 110 & 110 & 110 & 110 \\
Pseudo R $^{2}$ & 0.101 & 0.026 & 0.001 & 0.122 & 0.039 & 0.005 & 0.025 & 0.006 & 0.000 \\
\hline \hline
\end{tabular}

Notes: The table shows results from simple ordered probit models that explain the change in policy rates (in basis points) using the tone variable at different horizons. Numbers in brackets are standard errors. $* * * / * * / *$ denote statistical significance at the $1 \% / 5 \% / 10 \%$ level. 
Table 4: The effect of Bank of Canada press releases on 1-year government bond yields

\begin{tabular}{|c|c|c|c|c|c|c|c|c|}
\hline & $\begin{array}{c}\mathbf{1}) \\
\text { Baseline } \\
\end{array}$ & $\begin{array}{c}(2) \\
\text { Entire release } \\
\end{array}$ & $\begin{array}{l}\text { (3) } \\
\text { Past } \\
\end{array}$ & $\begin{array}{c}(4) \\
\text { Future }\end{array}$ & $\begin{array}{c}\text { (5) } \\
\text { Domestic } \\
\end{array}$ & $\begin{array}{c}6) \\
\text { Global } \\
\end{array}$ & $\begin{array}{c}(7) \\
\text { Inflation } \\
\end{array}$ & $\begin{array}{c}\text { (8) } \\
\text { Exchange rate } \\
\end{array}$ \\
\hline \multicolumn{9}{|l|}{ Mean equation } \\
\hline First lag & $\begin{array}{l}0.031^{*} \\
(0.018)\end{array}$ & $\begin{array}{c}0.028 \\
(0.018)\end{array}$ & $\begin{array}{c}0.028 \\
(0.018)\end{array}$ & $\begin{array}{c}0.029 \\
(0.018)\end{array}$ & $\begin{array}{c}0.028 \\
(0.018)\end{array}$ & $\begin{array}{l}0.032^{*} \\
(0.018)\end{array}$ & $\begin{array}{c}0.030 \\
(0.019)\end{array}$ & $\begin{array}{l}0.032^{*} \\
(0.019)\end{array}$ \\
\hline Surprise & $\begin{array}{c}0.916 * * * \\
(0.044)\end{array}$ & $\begin{array}{c}0.849 * * * \\
(0.046)\end{array}$ & $\begin{array}{c}0.848 * * * \\
(0.047)\end{array}$ & $\begin{array}{c}0.908 * * * \\
(0.040)\end{array}$ & $\begin{array}{c}0.892^{* * *} \\
(0.043)\end{array}$ & $\begin{array}{c}0.899 * * * \\
(0.046)\end{array}$ & $\begin{array}{c}0.872^{* * *} \\
(0.045)\end{array}$ & $\begin{array}{c}0.954 * * * \\
(0.039)\end{array}$ \\
\hline Word share balance & & $\begin{array}{c}0.031^{* * *} \\
(0.002)\end{array}$ & $\begin{array}{c}0.019 * * * \\
(0.001)\end{array}$ & $\begin{array}{c}0.022 * * * \\
(0.002)\end{array}$ & $\begin{array}{c}0.017^{* * * *} \\
(0.002)\end{array}$ & $\begin{array}{c}0.014^{* * *} \\
(0.002)\end{array}$ & $\begin{array}{c}0.010^{* * *} \\
(0.002)\end{array}$ & $\begin{array}{c}0.007 * * * \\
(0.001)\end{array}$ \\
\hline Constant & $\begin{array}{c}0.000 \\
(0.000)\end{array}$ & $\begin{array}{c}0.000 \\
(0.000)\end{array}$ & $\begin{array}{c}0.000 \\
(0.000)\end{array}$ & $\begin{array}{c}0.000 \\
(0.000)\end{array}$ & $\begin{array}{c}0.000 \\
(0.000)\end{array}$ & $\begin{array}{c}0.000 \\
(0.000)\end{array}$ & $\begin{array}{c}0.000 \\
(0.000)\end{array}$ & $\begin{array}{c}0.000 \\
(0.000)\end{array}$ \\
\hline \multicolumn{9}{|l|}{ Variance equation } \\
\hline Absolute surprise & $\begin{array}{c}28.863 * * * \\
(1.464)\end{array}$ & $\begin{array}{c}14.654^{* * *} \\
(2.494)\end{array}$ & $\begin{array}{c}44.382 \\
(43.258)\end{array}$ & $\begin{array}{c}8.508 * * * \\
(1.252)\end{array}$ & $\begin{array}{c}13.903 * * * \\
(2.023)\end{array}$ & $\begin{array}{c}22.237^{* * *} \\
(8.163)\end{array}$ & $\begin{array}{l}34.055^{*} \\
(17.945)\end{array}$ & $\begin{array}{c}17.254^{* * *} \\
(1.400)\end{array}$ \\
\hline Similarity & & $\begin{array}{c}-5.019 * * * \\
(1.087)\end{array}$ & $\begin{array}{c}3.948 \\
(12.096)\end{array}$ & $\begin{array}{c}-15.021^{* * *} \\
(2.995)\end{array}$ & $\begin{array}{c}-4.735^{* * *} \\
(0.853)\end{array}$ & $\begin{array}{l}-1.877 \\
(2.287)\end{array}$ & $\begin{array}{c}1.483 \\
(5.550)\end{array}$ & $\begin{array}{c}-4.252^{* * *} \\
(0.320)\end{array}$ \\
\hline Constant & $\begin{array}{c}-13.636^{* * *} \\
(0.230)\end{array}$ & $\begin{array}{c}-9.258^{* * *} \\
(0.713)\end{array}$ & $\begin{array}{l}-17.693 \\
(12.100)\end{array}$ & $\begin{array}{c}-7.485^{* * *} \\
(0.276)\end{array}$ & $\begin{array}{c}-9.440 * * * \\
(0.508)\end{array}$ & $\begin{array}{c}-11.867^{* * *} \\
(2.092)\end{array}$ & $\begin{array}{c}-15.118^{* * *} \\
(5.538)\end{array}$ & $\begin{array}{c}-9.606 * * * \\
(0.179)\end{array}$ \\
\hline \multicolumn{9}{|l|}{ ARCH terms } \\
\hline L.arch & $\begin{array}{c}0.083^{* * * *} \\
(0.004)\end{array}$ & $\begin{array}{c}0.085^{* * *} \\
(0.004)\end{array}$ & $\begin{array}{c}0.083^{* * *} \\
(0.004)\end{array}$ & $\begin{array}{c}0.084 * * * \\
(0.004)\end{array}$ & $\begin{array}{c}0.084^{* * *} \\
(0.004)\end{array}$ & $\begin{array}{c}0.086^{* * *} \\
(0.004)\end{array}$ & $\begin{array}{c}0.084 * * * \\
(0.004)\end{array}$ & $\begin{array}{c}0.086^{* * *} \\
(0.004)\end{array}$ \\
\hline L.garch & $\begin{array}{c}0.926^{* * *} \\
(0.003) \\
\end{array}$ & $\begin{array}{c}0.923 * * * \\
(0.003) \\
\end{array}$ & $\begin{array}{c}0.925^{* * *} \\
(0.003) \\
\end{array}$ & $\begin{array}{c}0.924 * * * \\
(0.003) \\
\end{array}$ & $\begin{array}{c}0.923 * * * \\
(0.003) \\
\end{array}$ & $\begin{array}{c}0.924 * * * \\
(0.003) \\
\end{array}$ & $\begin{array}{c}0.925^{* * *} \\
(0.003) \\
\end{array}$ & $\begin{array}{c}0.922^{* * *} \\
(0.003) \\
\end{array}$ \\
\hline Observations & 3,430 & 3,430 & 3,430 & 3,430 & 3,430 & 3,430 & 3,430 & 3,430 \\
\hline Log likelihood & 7,125 & 7,143 & 7,137 & 7,142 & 7,135 & 7,131 & 7,130 & 7,133 \\
\hline
\end{tabular}

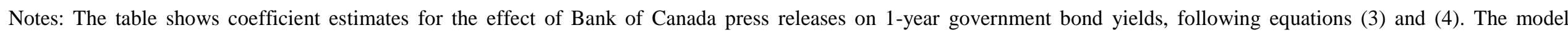

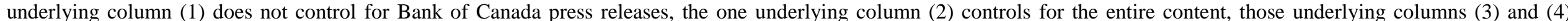

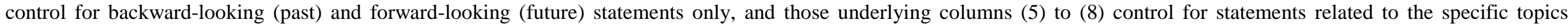
indicated in the header of the column. Numbers in brackets are standard errors. $* * * / * * / *$ denote statistical significance at the $1 \% / 5 \% / 10 \%$ level. 
Table 5: The effect of Bank of Canada press releases on different financial markets

\begin{tabular}{|c|c|c|c|c|c|c|c|c|c|c|c|c|c|}
\hline & \multicolumn{3}{|c|}{ Money market } & \multicolumn{7}{|c|}{ Government of Canada bonds } & \multicolumn{2}{|c|}{ Exchange rates } & \multirow{2}{*}{$\begin{array}{c}\begin{array}{c}\text { Stock market } \\
\mathrm{MSCl}\end{array} \\
\end{array}$} \\
\hline & 3-month & 6-month & 12-month & 3-month & 6-month & 12-month & 2-year & 5-year & 10-year & 30-year & USD/CAD & CERI & \\
\hline \multicolumn{14}{|l|}{ Control variables } \\
\hline First lag & $\begin{array}{c}-0.097 * * * \\
(0.016)\end{array}$ & $\begin{array}{c}0.137 * * * \\
(0.014)\end{array}$ & $\begin{array}{c}0.125^{* * *} \\
(0.015)\end{array}$ & $\begin{array}{l}-0.013 \\
(0.018)\end{array}$ & $\begin{array}{c}-0.056 * * * \\
(0.019)\end{array}$ & $\begin{array}{c}0.028 \\
(0.018)\end{array}$ & $\begin{array}{c}0.023 \\
(0.018)\end{array}$ & $\begin{array}{c}0.015 \\
(0.018)\end{array}$ & $\begin{array}{l}-0.004 \\
(0.017)\end{array}$ & $\begin{array}{c}0.019 \\
(0.017)\end{array}$ & $\begin{array}{c}-0.073 * * * \\
(0.017)\end{array}$ & $\begin{array}{l}-0.012 \\
(0.017)\end{array}$ & $\begin{array}{c}0.087 * * * \\
(0.012)\end{array}$ \\
\hline Energy index & -- & -- & -- & -- & -- & -- & -- & -- & -- & -- & $\begin{array}{c}0.047 * * * \\
(0.003)\end{array}$ & $\begin{array}{c}0.034 * * * \\
(0.003)\end{array}$ & -- \\
\hline Non-energy index & -- & -- & -- & -- & -- & -- & -- & -- & -- & -- & $\begin{array}{c}0.188 * * * \\
(0.014)\end{array}$ & $\begin{array}{c}0.225^{* * *} \\
(0.013)\end{array}$ & -- \\
\hline Rate differential & -- & -- & -- & -- & -- & -- & -- & -- & -- & -- & $\begin{array}{l}0.326^{*} \\
(0.169)\end{array}$ & $\begin{array}{c}0.714^{* * *} \\
(0.159)\end{array}$ & -- \\
\hline U.S. MSCl & -- & -- & -- & -- & -- & -- & -- & -- & -- & -- & -- & -- & $\begin{array}{c}0.748 * * * \\
(0.011)\end{array}$ \\
\hline Constant & $\begin{array}{l}0.000 \\
(0.000)\end{array}$ & $\begin{array}{c}0.000 \\
(0.000)\end{array}$ & $\begin{array}{l}-0.000 \\
(0.000)\end{array}$ & $\begin{array}{c}0.000 \\
(0.000)\end{array}$ & $\begin{array}{l}0.000 \\
(0.000)\end{array}$ & $\begin{array}{c}0.000 \\
(0.000)\end{array}$ & $\begin{array}{l}0.000 \\
(0.001)\end{array}$ & $\begin{array}{l}-0.000 \\
(0.001)\end{array}$ & $\begin{array}{l}-0.001 \\
(0.001)\end{array}$ & $\begin{array}{l}-0.001 \\
(0.001)\end{array}$ & $\begin{array}{c}0.004 \\
(0.008)\end{array}$ & $\begin{array}{c}0.001 \\
(0.007)\end{array}$ & $\begin{array}{c}0.000 \\
(0.000)\end{array}$ \\
\hline \multicolumn{14}{|l|}{ Mean equation } \\
\hline Surprise mean & $\begin{array}{c}0.904 * * * \\
(0.023)\end{array}$ & $\begin{array}{c}1.061^{* * *} \\
(0.025)\end{array}$ & $\begin{array}{c}1.025^{* * *} \\
(0.021)\end{array}$ & $\begin{array}{c}0.831^{* * *} \\
(0.025)\end{array}$ & $\begin{array}{c}0.851^{* * *} \\
(0.038)\end{array}$ & $\begin{array}{c}0.849 * * * \\
(0.046)\end{array}$ & $\begin{array}{c}0.705^{* * *} \\
(0.062)\end{array}$ & $\begin{array}{c}0.396 * * * \\
(0.071)\end{array}$ & $\begin{array}{c}0.166^{* *} \\
(0.076)\end{array}$ & $\begin{array}{c}0.019 \\
(0.069)\end{array}$ & $\begin{array}{c}3.336^{* * *} \\
(0.661)\end{array}$ & $\begin{array}{c}3.093^{* * *} \\
(0.666)\end{array}$ & $\begin{array}{c}0.009 \\
(0.017)\end{array}$ \\
\hline Statement balance & $\begin{array}{c}-0.005^{* * *} \\
(0.000)\end{array}$ & $\begin{array}{c}0.013^{* * *} \\
(0.001)\end{array}$ & $\begin{array}{c}0.026 * * * \\
(0.001)\end{array}$ & $\begin{array}{c}0.019 * * * \\
(0.002)\end{array}$ & $\begin{array}{c}0.025^{* * * *} \\
(0.002)\end{array}$ & $\begin{array}{c}0.031^{* * *} \\
(0.002)\end{array}$ & $\begin{array}{c}0.034 * * * \\
(0.006)\end{array}$ & $\begin{array}{l}0.016^{*} \\
(0.009)\end{array}$ & $\begin{array}{l}-0.007 \\
(0.010)\end{array}$ & $\begin{array}{l}-0.012 \\
(0.009)\end{array}$ & $\begin{array}{c}0.186 \\
(0.115)\end{array}$ & $\begin{array}{c}0.343^{* * *} \\
(0.103)\end{array}$ & $\begin{array}{c}0.002 \\
(0.002)\end{array}$ \\
\hline \multicolumn{14}{|l|}{ Variance equation } \\
\hline Absolute surprise & $\begin{array}{c}22.562 * * * \\
(1.515)\end{array}$ & $\begin{array}{c}17.927^{* * *} \\
(1.242)\end{array}$ & $\begin{array}{c}13.293 * * * \\
(1.865)\end{array}$ & $\begin{array}{c}9.462 * * * \\
(1.297)\end{array}$ & $\begin{array}{c}22.745^{* * *} \\
(7.009)\end{array}$ & $\begin{array}{c}14.654 * * * \\
(2.494)\end{array}$ & $\begin{array}{c}52.140 \\
(97.698)\end{array}$ & $\begin{array}{c}147.451 * * \\
(74.918)\end{array}$ & $\begin{array}{c}114.377 \\
(132.944)\end{array}$ & $\begin{array}{c}18.304 \\
(33.630)\end{array}$ & $\begin{array}{c}-5.789 \\
(17.959)\end{array}$ & $\begin{array}{c}2.316 \\
(3.213)\end{array}$ & $\begin{array}{c}9.055 \\
(7.655)\end{array}$ \\
\hline Similarity & $\begin{array}{c}-3.162^{* * *} \\
(0.417)\end{array}$ & $\begin{array}{c}-7.492^{* * *} \\
(0.496)\end{array}$ & $\begin{array}{c}-5.280 * * * \\
(0.616)\end{array}$ & $\begin{array}{c}-4.010^{* * *} \\
(0.306)\end{array}$ & $\begin{array}{l}-1.587 \\
(2.135)\end{array}$ & $\begin{array}{c}-5.019 * * * \\
(1.087)\end{array}$ & $\begin{array}{c}9.782 \\
(29.500)\end{array}$ & $\begin{array}{l}40.182^{*} \\
(24.415)\end{array}$ & $\begin{array}{c}31.357 \\
(42.255)\end{array}$ & $\begin{array}{c}2.525 \\
(9.672)\end{array}$ & $\begin{array}{c}-3.814 * * * \\
(0.881)\end{array}$ & $\begin{array}{c}-4.665 * * * \\
(0.727)\end{array}$ & $\begin{array}{l}-2.489 \\
(1.700)\end{array}$ \\
\hline Constant & $\begin{array}{c}-11.873^{* * *} \\
(0.379)\end{array}$ & $\begin{array}{c}-9.891 * * * \\
(0.202)\end{array}$ & $\begin{array}{c}-10.192^{* * *} \\
(0.350)\end{array}$ & $\begin{array}{c}-8.898 * * * \\
(0.218)\end{array}$ & $\begin{array}{c}-12.280 * * * \\
(2.006)\end{array}$ & $\begin{array}{c}-9.258^{* * *} \\
(0.713)\end{array}$ & $\begin{array}{l}-21.854 \\
(29.494)\end{array}$ & $\begin{array}{c}-51.188^{* *} \\
(24.439)\end{array}$ & $\begin{array}{l}-41.978 \\
(42.264)\end{array}$ & $\begin{array}{l}-12.730 \\
(9.616)\end{array}$ & $\begin{array}{c}-2.560^{* * *} \\
(0.614)\end{array}$ & $\begin{array}{c}-2.420^{* * *} \\
(0.450)\end{array}$ & $\begin{array}{c}-12.297^{* * *} \\
(1.513)\end{array}$ \\
\hline \multicolumn{14}{|l|}{ ARCH terms } \\
\hline L.arch & $\begin{array}{c}0.118^{* * *} \\
(0.004)\end{array}$ & $\begin{array}{c}0.140 * * * \\
(0.005)\end{array}$ & $\begin{array}{c}0.083 * * * \\
(0.004)\end{array}$ & $\begin{array}{c}0.111^{* * *} \\
(0.004)\end{array}$ & $\begin{array}{c}0.090 * * * \\
(0.003)\end{array}$ & $\begin{array}{c}0.085 * * * \\
(0.004)\end{array}$ & $\begin{array}{c}0.055 * * * \\
(0.004)\end{array}$ & $\begin{array}{c}0.040 * * * \\
(0.004)\end{array}$ & $\begin{array}{c}0.041 * * * \\
(0.005)\end{array}$ & $\begin{array}{c}0.052^{* * *} \\
(0.007)\end{array}$ & $\begin{array}{c}0.055^{* * *} \\
(0.006)\end{array}$ & $\begin{array}{c}0.044^{* * *} \\
(0.005)\end{array}$ & $\begin{array}{c}0.060 * * * \\
(0.005)\end{array}$ \\
\hline L.garch & $\begin{array}{c}0.899 * * * \\
(0.002) \\
\end{array}$ & $\begin{array}{c}0.890 * * * \\
(0.003) \\
\end{array}$ & $\begin{array}{c}0.926 * * * \\
(0.003) \\
\end{array}$ & $\begin{array}{c}0.890 * * * \\
(0.003) \\
\end{array}$ & $\begin{array}{c}0.920 * * * \\
(0.002) \\
\end{array}$ & $\begin{array}{c}0.923 * * * \\
(0.003) \\
\end{array}$ & $\begin{array}{c}0.945^{* * *} \\
(0.003) \\
\end{array}$ & $\begin{array}{c}0.954^{* * *} \\
(0.004) \\
\end{array}$ & $\begin{array}{c}0.948 * * * \\
(0.007) \\
\end{array}$ & $\begin{array}{c}0.921 * * * \\
(0.012) \\
\end{array}$ & $\begin{array}{c}0.937^{* * *} \\
(0.007) \\
\end{array}$ & $\begin{array}{c}0.949 * * * \\
(0.006) \\
\end{array}$ & $\begin{array}{c}0.936 * * * \\
(0.005) \\
\end{array}$ \\
\hline $\begin{array}{l}\text { Observations } \\
\text { Log likelihood }\end{array}$ & $\begin{array}{c}3,430 \\
10,167\end{array}$ & $\begin{array}{c}3,430 \\
10,042\end{array}$ & $\begin{array}{l}3,427 \\
8,422\end{array}$ & $\begin{array}{l}3,430 \\
9,062\end{array}$ & $\begin{array}{l}3,430 \\
8,251\end{array}$ & $\begin{array}{l}3,430 \\
7,143\end{array}$ & $\begin{array}{l}3,430 \\
5,898\end{array}$ & $\begin{array}{l}3,430 \\
5,477\end{array}$ & $\begin{array}{l}3,430 \\
5,745\end{array}$ & $\begin{array}{l}3,430 \\
6,540\end{array}$ & $\begin{array}{l}3,428 \\
-2,543\end{array}$ & $\begin{array}{l}3,428 \\
-2,275\end{array}$ & $\begin{array}{c}3,430 \\
11,490\end{array}$ \\
\hline
\end{tabular}

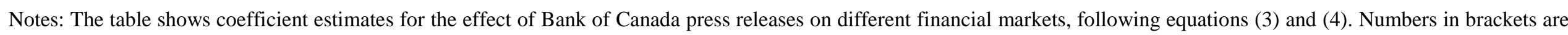
standard errors. $* * * / * * / *$ denote statistical significance at the $1 \% / 5 \% / 10 \%$ level. 
Table 6: The effect on 1-year government bond yields-interaction terms

\begin{tabular}{|c|c|c|c|c|}
\hline & & graph & & count \\
\hline & $\begin{array}{c}\text { (1) } \\
\text { Benchmark } \\
\end{array}$ & $\begin{array}{c}\text { (2) } \\
\text { Including interaction }\end{array}$ & $\begin{array}{c}\text { (3) } \\
\text { Benchmark }\end{array}$ & $\begin{array}{c}(4) \\
\text { Including interaction }\end{array}$ \\
\hline Mean equation & & & & \\
\hline First lag & $\begin{array}{l}0.028 \\
(0.018)\end{array}$ & $\begin{array}{l}0.026 \\
(0.018)\end{array}$ & $\begin{array}{l}0.028 \\
(0.018)\end{array}$ & $\begin{array}{l}0.027 \\
(0.018)\end{array}$ \\
\hline Surprise & $\begin{array}{c}0.911 * * * \\
(0.042)\end{array}$ & $\begin{array}{c}0.906 * * * \\
(0.043)\end{array}$ & $\begin{array}{c}0.860 * * * \\
(0.048)\end{array}$ & $\begin{array}{c}0.849 * * * \\
(0.048)\end{array}$ \\
\hline Word share balance & $\begin{array}{c}0.022^{* * *} \\
(0.004)\end{array}$ & $\begin{array}{c}0.014^{* * *} \\
(0.004)\end{array}$ & $\begin{array}{c}0.032^{* * *} \\
(0.002)\end{array}$ & $\begin{array}{c}0.032^{* * *} \\
(0.002)\end{array}$ \\
\hline Constant & $\begin{array}{c}0.000 \\
(0.000)\end{array}$ & $\begin{array}{l}0.000 \\
(0.000)\end{array}$ & $\begin{array}{c}0.000 \\
(0.000)\end{array}$ & $\begin{array}{c}0.000 \\
(0.000)\end{array}$ \\
\hline Variance equation & & & & \\
\hline Absolute surprise & $\begin{array}{c}7.218^{* * *} \\
(1.199)\end{array}$ & $\begin{array}{c}15.361^{* * *} \\
(3.323)\end{array}$ & $\begin{array}{c}15.350 * * * \\
(2.041)\end{array}$ & $\begin{array}{c}15.590 * * * \\
(2.086)\end{array}$ \\
\hline Similarity & $\begin{array}{c}-6.705^{* * *} \\
(0.440)\end{array}$ & $\begin{array}{c}-4.119 * * * \\
(1.045)\end{array}$ & $\begin{array}{c}-5.551^{* * *} \\
(0.961)\end{array}$ & $\begin{array}{c}-5.874^{* * *} \\
(1.221)\end{array}$ \\
\hline$D_{t_{-1}} / \Delta$ word count & -- & $\begin{array}{c}3.614^{* * *} \\
(0.955)\end{array}$ & $\begin{array}{c}-0.005^{* * *} \\
(0.001)\end{array}$ & $\begin{array}{c}0.001 \\
(0.003)\end{array}$ \\
\hline Interaction & -- & $\begin{array}{c}-6.087 * * * \\
(2.074)\end{array}$ & -- & $\begin{array}{c}-0.029 * * \\
(0.015)\end{array}$ \\
\hline Constant & $\begin{array}{c}-7.569 * * * \\
(0.163)\end{array}$ & $\begin{array}{c}-9.845^{* * *} \\
(0.928)\end{array}$ & $\begin{array}{c}-8.878^{* * *} \\
(0.531)\end{array}$ & $\begin{array}{l}-8.955^{* * *} \\
(0.588)\end{array}$ \\
\hline ARCH terms & & & & \\
\hline L.arch & $\begin{array}{c}0.086 * * * \\
(0.004)\end{array}$ & $\begin{array}{c}0.084 * * * \\
(0.004)\end{array}$ & $\begin{array}{c}0.088^{* * *} \\
(0.004)\end{array}$ & $\begin{array}{c}0.087 * * * \\
(0.004)\end{array}$ \\
\hline L.garch & $\begin{array}{c}0.919 * * * \\
(0.003) \\
\end{array}$ & $\begin{array}{c}0.921^{* * *} \\
(0.003) \\
\end{array}$ & $\begin{array}{c}0.920^{* * *} \\
(0.003)\end{array}$ & $\begin{array}{c}0.920 * * * \\
(0.003) \\
\end{array}$ \\
\hline $\begin{array}{l}\text { Observations } \\
\text { Log likelihood }\end{array}$ & $\begin{array}{l}3,430 \\
7,151\end{array}$ & $\begin{array}{l}3,430 \\
7,165\end{array}$ & $\begin{array}{l}3,430 \\
7,146\end{array}$ & $\begin{array}{l}3,430 \\
7,148\end{array}$ \\
\hline
\end{tabular}

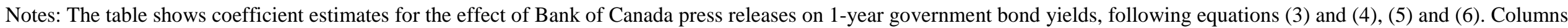

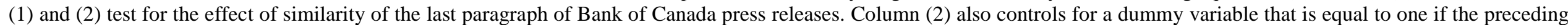

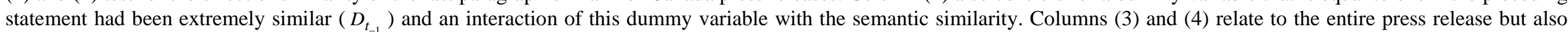

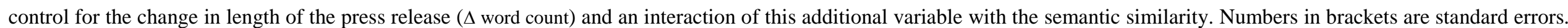
$* * * / * * / *$ denote statistical significance at the $1 \% / 5 \% / 10 \%$ level. 
Table 7: The effect of Bank of Canada press releases on 1-year government bond yields—robustness tests

\begin{tabular}{|c|c|c|c|c|c|c|c|}
\hline & $\begin{array}{c}\text { (1) } \\
\text { Benchmark }\end{array}$ & $\begin{array}{c}(2) \\
\text { Reversed } \\
\text { fx coding }\end{array}$ & $\begin{array}{c}\text { (3) } \\
\text { Add forecast } \\
\text { dispersion }\end{array}$ & $\begin{array}{c}(4) \\
\text { Add macro } \\
\text { news }\end{array}$ & $\begin{array}{c}(5) \\
\Delta \text { balance }\end{array}$ & $\begin{array}{c}(6) \\
\text { Add MPR }\end{array}$ & $\begin{array}{c}\text { (7) } \\
\text { EGARCH }\end{array}$ \\
\hline \multicolumn{8}{|l|}{ Mean equation } \\
\hline First lag & $\begin{array}{c}0.028 \\
(0.018)\end{array}$ & $\begin{array}{c}0.029 \\
(0.018)\end{array}$ & $\begin{array}{c}0.030 \\
(0.019)\end{array}$ & $\begin{array}{c}0.028 \\
(0.018)\end{array}$ & $\begin{array}{l}0.032^{*} \\
(0.018)\end{array}$ & $\begin{array}{c}0.027 \\
(0.018)\end{array}$ & $\begin{array}{l}0.033^{*} \\
(0.018)\end{array}$ \\
\hline Second lag & -- & -- & -- & -- & -- & -- & $\begin{array}{c}-0.002 \\
(0.017)\end{array}$ \\
\hline Surprise & $\begin{array}{c}0.849 * * * \\
(0.046)\end{array}$ & $\begin{array}{c}0.858^{* * *} \\
(0.046)\end{array}$ & $\begin{array}{c}0.903 * * * \\
(0.041)\end{array}$ & $\begin{array}{c}0.853^{* * *} \\
(0.045)\end{array}$ & $\begin{array}{c}0.876^{* * *} \\
(0.044)\end{array}$ & $\begin{array}{c}0.856^{* * *} \\
(0.047)\end{array}$ & $\begin{array}{c}1.019 * * * \\
(0.029)\end{array}$ \\
\hline Word share balance & $\begin{array}{c}0.031^{* * *} \\
(0.002)\end{array}$ & $\begin{array}{c}0.025^{* * *} \\
(0.002)\end{array}$ & $\begin{array}{c}0.030^{* * *} \\
(0.003)\end{array}$ & $\begin{array}{c}0.029 * * * \\
(0.002)\end{array}$ & $\begin{array}{c}0.034^{* * *} \\
(0.003)\end{array}$ & $\begin{array}{c}0.032^{* * *} \\
(0.002)\end{array}$ & $\begin{array}{c}0.025^{* * *} \\
(0.003)\end{array}$ \\
\hline Constant & $\begin{array}{c}0.000 \\
(0.000)\end{array}$ & $\begin{array}{c}0.000 \\
(0.000)\end{array}$ & $\begin{array}{c}0.000 \\
(0.000)\end{array}$ & $\begin{array}{l}-0.000 \\
(0.000)\end{array}$ & $\begin{array}{c}0.000 \\
(0.000)\end{array}$ & $\begin{array}{c}0.000 \\
(0.000)\end{array}$ & $\begin{array}{l}-0.000 \\
(0.000)\end{array}$ \\
\hline Current account (CAN) & -- & -- & -- & $\begin{array}{l}-0.000 \\
(0.002)\end{array}$ & -- & -- & -- \\
\hline PPI (CAN) & -- & -- & -- & $\begin{array}{l}-0.005 \\
(0.005)\end{array}$ & -- & -- & -- \\
\hline$\Delta$ Employment (\%) (CAN) & -- & -- & -- & $\begin{array}{c}0.000 * * * \\
(0.000)\end{array}$ & -- & -- & -- \\
\hline Raw materials PPI (CAN) & -- & -- & -- & $\begin{array}{l}-0.001 \\
(0.001)\end{array}$ & -- & -- & -- \\
\hline Non-farm payrolls (U.S.) & -- & -- & -- & $\begin{array}{c}0.000 * * * \\
(0.000)\end{array}$ & -- & -- & -- \\
\hline Industrial prod. (U.S.) & -- & -- & -- & $\begin{array}{c}0.004 \\
(0.004)\end{array}$ & -- & -- & -- \\
\hline Retail sales (U.S.) & -- & -- & -- & $\begin{array}{c}0.008 * * * \\
(0.002)\end{array}$ & -- & -- & -- \\
\hline
\end{tabular}


Table 7 (continued)

\begin{tabular}{|c|c|c|c|c|c|c|c|}
\hline & $\begin{array}{c}(1) \\
\text { Benchmark }\end{array}$ & $\begin{array}{c}(2) \\
\text { Reversed } \\
\text { fx coding } \\
\end{array}$ & $\begin{array}{c}\text { (3) } \\
\text { Add forecast } \\
\text { dispersion }\end{array}$ & $\begin{array}{c}4) \\
\text { Add macro } \\
\text { news }\end{array}$ & $\begin{array}{c}\text { (5) } \\
\Delta \text { balance }\end{array}$ & $\begin{array}{c}\text { (6) } \\
\text { Add MPR }\end{array}$ & $\begin{array}{c}\text { (7) } \\
\text { EGARCH }\end{array}$ \\
\hline \multicolumn{8}{|l|}{ Variance equation } \\
\hline Absolute surprise & $\begin{array}{l}14.654 * * * \\
(2.494)\end{array}$ & $\begin{array}{l}13.868^{* * *} \\
(2.249)\end{array}$ & $\begin{array}{l}10.827^{* * *} \\
(1.632)\end{array}$ & $\begin{array}{l}14.506^{* * *} \\
(2.183)\end{array}$ & $\begin{array}{l}13.051 * * * \\
(2.207)\end{array}$ & $\begin{array}{l}14.937^{* * *} \\
(2.610)\end{array}$ & $\begin{array}{l}1.699 * * * \\
(0.589)\end{array}$ \\
\hline Similarity & $\begin{array}{l}-5.019 * * * \\
(1.087)\end{array}$ & $\begin{array}{l}-5.215^{* * *} \\
(1.001)\end{array}$ & $\begin{array}{l}-3.893^{* * *} \\
(0.487)\end{array}$ & $\begin{array}{l}-5.470^{* * *} \\
(0.935)\end{array}$ & $\begin{array}{l}-5.152^{* * *} \\
(1.034)\end{array}$ & $\begin{array}{l}-6.025^{* * *} \\
(0.957)\end{array}$ & $\begin{array}{l}-0.365^{* * *} \\
(0.066)\end{array}$ \\
\hline $\begin{array}{l}\text { Additional variable (see } \\
\text { column header) }\end{array}$ & -- & -- & $\begin{array}{l}3.729 * * * \\
(0.290)\end{array}$ & -- & -- & $\begin{array}{l}-1.079 * \\
(0.558)\end{array}$ & -- \\
\hline Constant & $\begin{array}{l}-9.258^{* * *} \\
(0.713)\end{array}$ & $\begin{array}{l}-9.044 * * * \\
(0.627)\end{array}$ & $\begin{array}{l}-10.260 * * * \\
(0.420)\end{array}$ & $\begin{array}{l}-9.165^{* * *} \\
(0.601)\end{array}$ & $\begin{array}{l}-9.092^{* * *} \\
(0.613)\end{array}$ & $\begin{array}{l}-8.346 * * * \\
(0.536)\end{array}$ & $\begin{array}{l}0.293 * * * \\
(0.065)\end{array}$ \\
\hline Current account (CA) & -- & -- & -- & $\begin{array}{l}1.148 \\
(0.878)\end{array}$ & -- & -- & -- \\
\hline PPI (CA) & -- & -- & -- & $\begin{array}{l}3.919 * * \\
(1.893)\end{array}$ & -- & -- & -- \\
\hline$\Delta$ Employment (\%) (CA) & -- & -- & -- & $\begin{array}{l}-0.168^{* * *} \\
(0.061)\end{array}$ & -- & -- & -- \\
\hline Raw materials PPI (CA) & -- & -- & -- & $\begin{array}{l}0.056 \\
(0.786)\end{array}$ & -- & -- & -- \\
\hline Non-farm payrolls (U.S.) & -- & -- & -- & $\begin{array}{l}0.044 * * * \\
(0.004)\end{array}$ & -- & -- & -- \\
\hline Industrial prod. (U.S.) & -- & -- & -- & $\begin{array}{l}3.967 * * * \\
(1.341)\end{array}$ & -- & -- & -- \\
\hline $\begin{array}{l}\text { Retail sales (U.S.) } \\
\text { ARCH terms }\end{array}$ & -- & -- & -- & $\begin{array}{l}2.027 * * * \\
(0.174)\end{array}$ & -- & -- & -- \\
\hline L.arch/L.earch & $\begin{array}{l}0.085^{* * *} \\
(0.004)\end{array}$ & $\begin{array}{l}0.085^{* * *} \\
(0.004)\end{array}$ & $\begin{array}{l}0.086 * * * \\
(0.005)\end{array}$ & $\begin{array}{l}0.081^{* * *} \\
(0.004)\end{array}$ & $\begin{array}{l}0.085^{* * *} \\
(0.004)\end{array}$ & $\begin{array}{l}0.086 * * * \\
(0.004)\end{array}$ & $\begin{array}{l}-0.025^{* * *} \\
(0.005)\end{array}$ \\
\hline L.garch/L.egarch & $\begin{array}{l}0.923^{* * *} \\
(0.003)\end{array}$ & $\begin{array}{l}0.923^{* * *} \\
(0.003)\end{array}$ & $\begin{array}{l}0.914^{* * *} \\
(0.004)\end{array}$ & $\begin{array}{l}0.923^{* * *} \\
(0.003)\end{array}$ & $\begin{array}{l}0.924 * * * \\
(0.003)\end{array}$ & $\begin{array}{l}0.921^{* * *} \\
(0.003)\end{array}$ & $\begin{array}{l}0.209 * * * \\
(0.008)\end{array}$ \\
\hline L.earch_a & -- & -- & -- & -- & -- & -- & $\begin{array}{l}-0.025^{* * *} \\
(0.005) \\
\end{array}$ \\
\hline $\begin{array}{l}\text { Observations } \\
\text { Log likelihood }\end{array}$ & 3,430 & 3,430 & 3,430 & 3,430 & 3430 & 3,430 & 3,429 \\
\hline Log likelihood & 7,143 & 7,138 & 7,152 & 7,229 & 7,142 & 7,144 & 7,148 \\
\hline
\end{tabular}

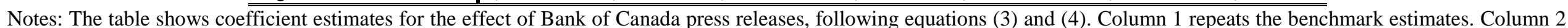

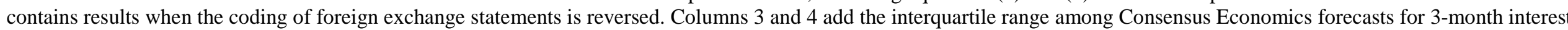

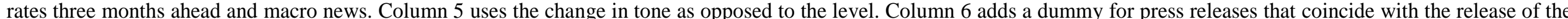

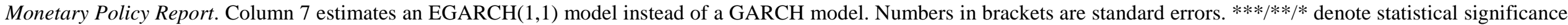
at the $1 \% / 5 \% / 10 \%$ level. 
Appendix Table A1: Examples of statement coding

\begin{tabular}{|c|c|c|c|}
\hline Topic & Tense & Tone & Examples \\
\hline \multirow{6}{*}{$\begin{array}{l}\text { Domestic } \\
\text { economy }\end{array}$} & \multirow{3}{*}{$\begin{array}{l}\text { Backward- } \\
\text { looking }\end{array}$} & Positive & "The Canadian economy continued to expand in the first quarter of 2003, reflecting firmness in domestic demand" \\
\hline & & Negative & "Economic growth in Canada moderated in the final three months of 2002" \\
\hline & & Neutral & "The Canadian economy has been growing broadly in line with the Bank's expectations" \\
\hline & \multirow{3}{*}{$\begin{array}{l}\text { Forward- } \\
\text { looking }\end{array}$} & Positive & "On the upside, there is a possibility that household demand in Canada could be stronger than anticipated." \\
\hline & & Negative & "Although temporary supply chain disruptions are expected to restrain growth sharply in the current quarter [...]" \\
\hline & & Neutral & "The Bank anticipates that business investment and net exports will make a relatively larger contribution to growth." \\
\hline \multirow{6}{*}{$\begin{array}{l}\text { Global } \\
\text { economy }\end{array}$} & \multirow{3}{*}{$\begin{array}{l}\text { Backward- } \\
\text { looking }\end{array}$} & Positive & "Since the July Monetary Policy Report Update (MPRU), the global economy has continued its solid expansion" \\
\hline & & Negative & "While there has been some moderation in U.S. economic growth [...]" \\
\hline & & Neutral & "U.S. economic activity has come in largely as expected" \\
\hline & \multirow{3}{*}{$\begin{array}{l}\text { Forward- } \\
\text { looking }\end{array}$} & Positive & "Strong growth in the United States is expected to resume in the second quarter of 2015" \\
\hline & & Negative & "[...] but over the medium term, risks related to global imbalances are increasing" \\
\hline & & Neutral & "Fiscal drag in the United States over the next two years remains consistent with the Bank's January projection" \\
\hline \multirow{6}{*}{ Inflation } & \multirow{3}{*}{$\begin{array}{l}\text { Backward- } \\
\text { looking }\end{array}$} & Positive & "Inflation has risen by more than expected. The increase in inflation over the past year is largely [...]" \\
\hline & & Negative & "However, other developments since October suggest that the downside risks to the Bank's inflation projection have increased." \\
\hline & & Neutral & "Canadian consumer price data for January show core inflation at 1.8 per cent and total CPI inflation at 1.3 per cent." \\
\hline & \multirow{3}{*}{$\begin{array}{l}\text { Forward- } \\
\text { looking }\end{array}$} & Positive & "In these circumstances, the persistence of above-target rates of inflation has elevated the risk of an increase in inflation expectations" \\
\hline & & Negative & $\begin{array}{c}\text { "[...] it now appears that both core and total CPI inflation will return to the } 2 \text { per cent target somewhat earlier than the Bank expected in April." (after period of } \\
\text { above-target inflation) }\end{array}$ \\
\hline & & Neutral & $\begin{array}{c}\text { "As the economy reaches and remains at full capacity around the end of 2016, both total and core inflation are projected to be close to } 2 \text { per cent on a sustained } \\
\text { basis." }\end{array}$ \\
\hline \multirow{6}{*}{$\begin{array}{l}\text { Exchange } \\
\text { rate }\end{array}$} & \multirow{3}{*}{$\begin{array}{l}\text { Backward- } \\
\text { looking }\end{array}$} & Positive & "[...] and the Canadian dollar has traded in a higher range against the U.S. dollar and other major currencies" \\
\hline & & Negative & "The reduction in commodity prices has been a significant factor in the decline of the Canadian dollar against the U.S. dollar" \\
\hline & & Neutral & "The Canadian dollar has also largely traded in the range assumed in the July MPRU" \\
\hline & \multirow{3}{*}{$\begin{array}{l}\text { Forward- } \\
\text { looking }\end{array}$} & Positive & "These challenges include the persistent strength of the Canadian dollar, which is being influenced by safe-haven flows and [...]" \\
\hline & & Negative & "Consequently, the effects on core inflation of the lower dollar and the output gap will continue to offset each other." \\
\hline & & Neutral & "However, there is uncertainty about the extent to which the appreciation of the Canadian dollar will offset the effects of [...]" \\
\hline $\begin{array}{l}\text { None of } \\
\text { the above }\end{array}$ & & & "The interest rate cut announced today brings the cumulative easing in the target for the overnight rate over the past 12 months to $33 / 4$ percentage points." \\
\hline
\end{tabular}


Appendix Table A2: Summary statistics of financial market variables

\begin{tabular}{l|lllll}
\hline \hline $\begin{array}{l}\text { Financial market variables } \\
\text { (differences / growth rates) }\end{array}$ & Obs & Mean & Std. Dev. & Min & Max \\
\hline Money markets & & & & & \\
3-month & 3,431 & -0.001 & 0.025 & -0.410 & 0.250 \\
6-month & 3,431 & -0.000 & 0.025 & -0.299 & 0.211 \\
12-month & 3,429 & -0.000 & 0.034 & -0.257 & 0.351 \\
\hline Government bonds & & & & & \\
3-month & 3,431 & -0.001 & 0.039 & -0.560 & 1.030 \\
6-month & 3,431 & -0.001 & 0.034 & -0.320 & 0.450 \\
12-month & 3,431 & -0.001 & 0.042 & -0.680 & 0.420 \\
2-year & 3,431 & -0.001 & 0.052 & -0.340 & 0.320 \\
5-year & 3,431 & -0.001 & 0.053 & -0.280 & 0.330 \\
10-year & 3,431 & -0.001 & 0.047 & -0.230 & 0.240 \\
30-year & 3,431 & -0.001 & 0.037 & -0.150 & 0.210 \\
\hline Exchange rates & 3,431 & 0.006 & 0.604 & -3.199 & 4.061 \\
USD/CAD & 3,431 & 0.007 & 0.565 & -3.664 & 4.739 \\
CERI & & & & & \\
\hline Stock market & 3,431 & 0.000 & 0.014 & -0.119 & 0.131 \\
MSCl index & \multicolumn{5}{|l}{} \\
\hline \hline
\end{tabular}

